Prepared in cooperation with the U.S. Department of the Army

Precipitation and Streamflow Data from the Fort Carson Military Reservation and Precipitation, Streamflow, and Suspended-Sediment Data from the Piñon Canyon Maneuver Site, Southeastern Colorado, 2008-2012

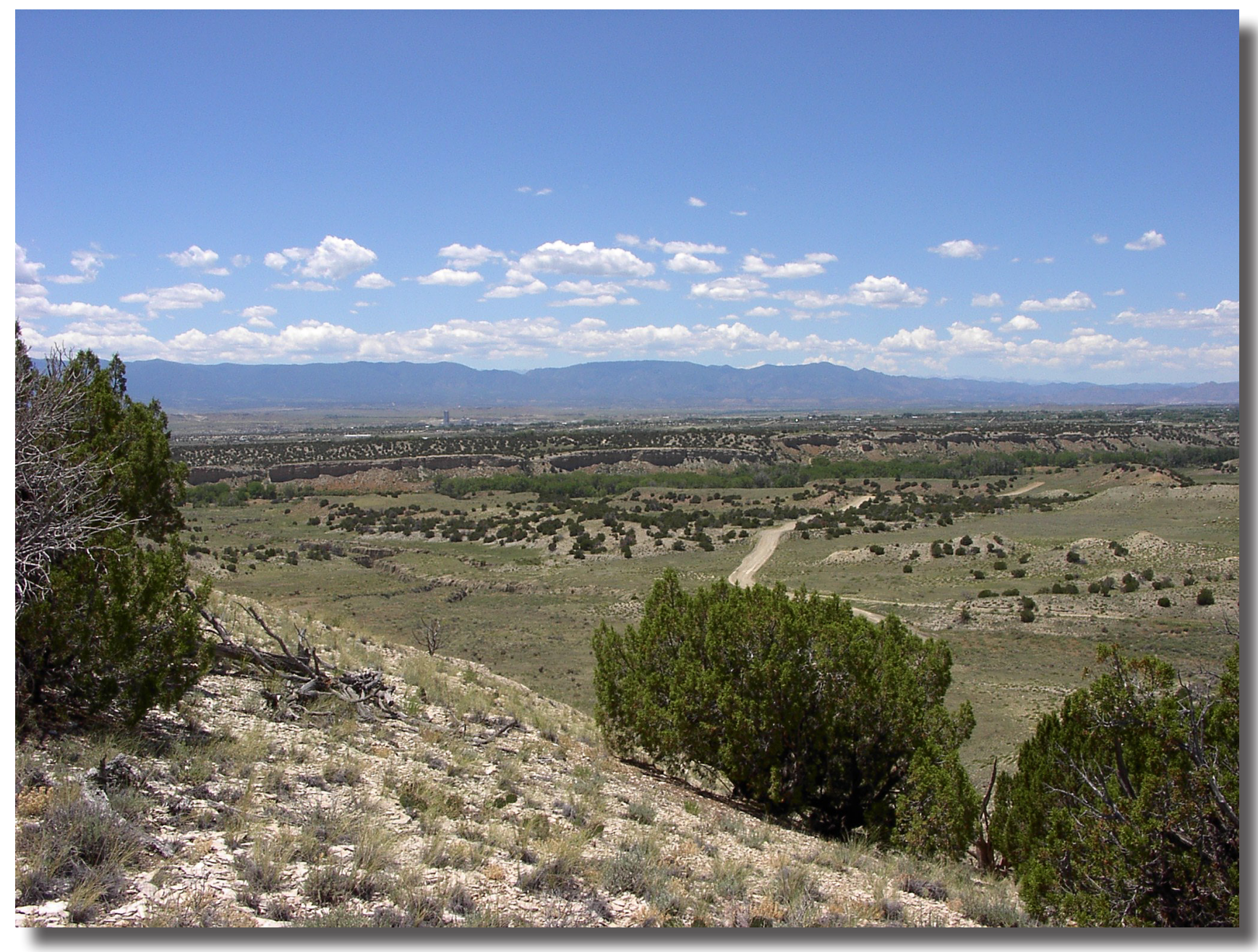

Open-File Report 2014-1039 


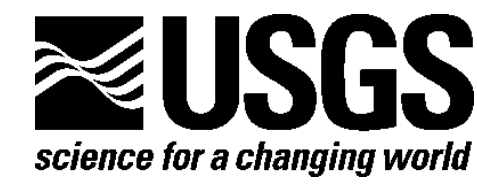

Prepared in cooperation with the U.S. Department of the Army

Precipitation and Streamflow Data from the Fort Carson Military Reservation and Precipitation, Streamflow, and Suspended-Sediment Data from the Piñon Canyon Maneuver Site, Southeastern Colorado, 2008-2012

By Christopher R. Brown

Open-File Report 2014-1039 


\section{U.S. Department of the Interior \\ SALLY JEWELL, Secretary}

\section{U.S. Geological Survey \\ SUZETTE M. KIMBALL, Acting Director}

U.S. Geological Survey, Reston, Virginia: 2014

For more information on the USGS-the Federal source for science about the Earth,

its natural and living resources, natural hazards, and the environment-visit

http://www.usgs.gov or call 1-888-ASK-USGS

For an overview of USGS information products, including maps, imagery, and publications, visit $h$ ttp://www.usgs.gov/pubprod

To order this and other USGS information products, visit $h$ ttp://store.usgs.gov

Suggested citation:

Brown, C.R., 2014, Precipitation and streamflow data from the Fort Carson Military Reservation and precipitation, streamflow, and suspended-sediment data from the Piñon Canyon Maneuver Site, Southeastern Colorado, 20082012: U.S. Geological Survey Open-File Report 2014-1039, 39 p., http://dx.doi.org/10.3133/ofr20141039.

ISSN 2331-1258 (online)

Any use of trade, firm, or product names is for descriptive purposes only and does not imply endorsement by the U.S. Government.

Although this information product, for the most part, is in the public domain, it also may contain copyrighted materials as noted in the text. Permission to reproduce copyrighted items must be secured from the copyright owner. 


\section{Contents}

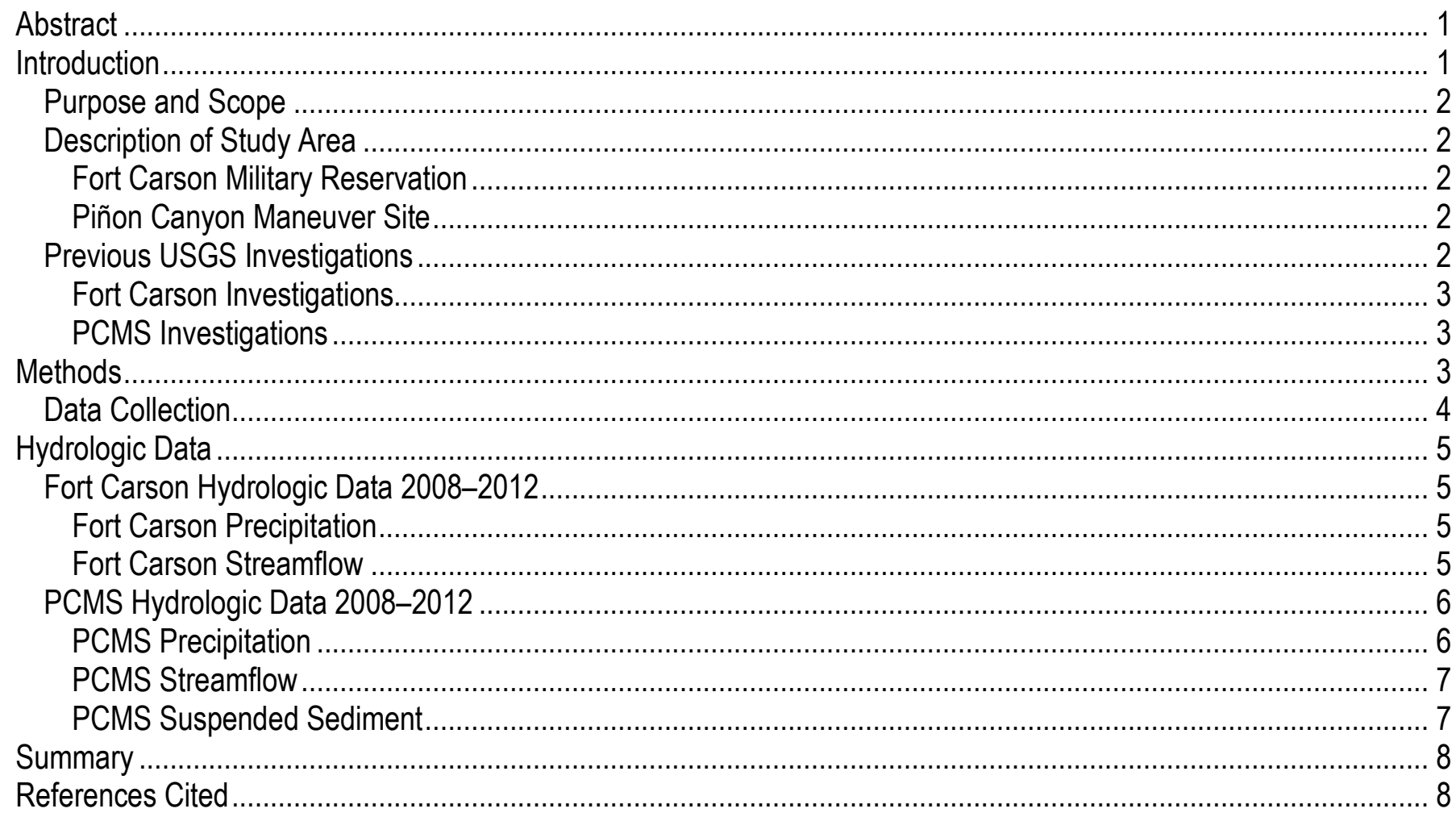

\section{Figures}

Figure 1. Location of precipitation and stream-gaging stations included in this study at the Fort Carson Military Reservation .......................................................................................................................... 10

Figure 2. Location of precipitation, stream-gaging, and sediment stations included in this study at the Piñon Canyon Maneuver Site

Figure 3. Maximum, minimum, and median monthly precipitation for Fort Carson Military Reservation precipitation stations, 2008-2012

Figure 4. A. Annual median precipitation by land-surface altitude (LSA) for the Fort Carson Military

Reservation, 2002-2012.

Figure 4. B. Comparison of precipitation amounts between different land-surface altitude (LSA) groups for the Fort Carson Military Reservation, 2002-2012.

Figure 5. Censored and truncated box plots showing daily precipitation values for Fort Carson Military Reservation precipitation stations

Figure 6. Annual mean streamflow for Turkey Creek near Fountain (USGS site number 07099215, Turkey Fountain)

Figure 7. Annual mean streamflow for Turkey Creek above Teller Reservoir (USGS site number 07099230, Turkey Teller)

Figure 8. Annual mean streamflow for Turkey Creek near Stone City (USGS site number 07099235, Turkey Stone)

Figure 9. Annual mean streamflow for Rock Creek above Fort Carson (USGS site number 07105945, Rock)...... 19 
Figure 10. Annual peak streamflow for Red Creek below Sullivan Park (USGS site number 07099080, Red).... 20 Figure 11. Maximum, minimum, and median monthly precipitation for Piñon Canyon Maneuver Site

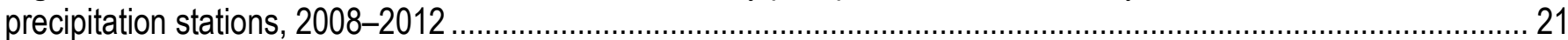

Figure 12. Maximum, minimum, and median monthly precipitation for seasonally monitored Piñon Canyon Maneuver Site precipitation stations, 2008-2012 .................................................................................... 22

Figure 13. A. Annual median precipitation by land-surface altitude (LSA) for the Piñon Canyon Maneuver Site, 2002-2012

Figure 13. B. Comparison of precipitation amounts between different land-surface altitude (LSA) groups for the Piñon Canyon Maneuver Site, 2002-2012

Figure 14. Censored and truncated box plots showing daily precipitation values for Piñon Canyon Maneuver Site precipitation stations.

Figure 15. Censored and truncated box plots showing daily precipitation values for seasonally monitored Piñon Canyon Maneuver Site precipitation stations.....

Figure 16. Annual mean streamflow for Purgatoire River near Thatcher (USGS site number 07126300,

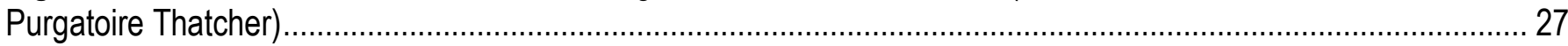

Figure 17. Annual mean streamflow for Purgatoire River at Rock Crossing (USGS site number 07126485,

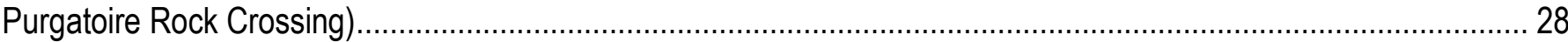

Figure 18. Percentage of annual mean streamflow at Purgatoire Rock Crossing (USGS site number 07126485) for tributary channels, Piñon Canyon Maneuver Site.....

Figure 19. Annual peak flow for six tributary stream-gaging stations (Big Arroyo, Van Bremer Model, Taylor, Lockwood Canyon, Red Rock, Bent) at the Piñon Canyon Maneuver Site, 1983-2012.

Figure 20. Total suspended-sediment yield for seasonally monitored suspended-sediment stations at the Piñon Canyon Maneuver Site: 2002-2007 and 2008-2012

Figure 21. Daily mean streamflow and suspended-sediment discharge for Van Bremer Arroyo near Model (USGS site number 07126200, Van Bremer Model), 2008-2012 ..................................................................... 32

Figure 22. Daily mean streamflow and suspended-sediment discharge for Taylor Arroyo below Rock Crossing (USGS site number 07126325, Taylor), 2008-2012.....

Figure 23. Daily mean streamflow and suspended-sediment discharge for Lockwood Canyon Creek near Thatcher (USGS site number 07126390, Lockwood Canyon), 2008-2012

Figure 24. Daily mean streamflow and suspended-sediment discharge for Red Rock Canyon at the mouth (USGS site number 07126415, Red Rock), 2008-2012

Figure 25. Daily mean streamflow and suspended-sediment discharge for Bent Canyon Creek at the mouth (USGS site number 07126480, Bent), 2008-2012

\section{Tables}

Table 1. Locations of the Fort Carson Military Reservation precipitation and stream-gaging stations.....

Table 2. Locations of the Piñon Canyon Maneuver Site precipitation, stream-gaging, and 


\section{Conversion Factors}

Inch/Pound to SI

\begin{tabular}{lcl}
\hline & \multicolumn{1}{c}{ Multiply } & \multicolumn{1}{c}{ To obtain } \\
\hline inch (in.) & Length & \\
inch (in.) & 2.54 & centimeter $(\mathrm{cm})$ \\
foot (ft) & 25.4 & millimeter $(\mathrm{mm})$ \\
mile (mi) & 0.3048 & meter $(\mathrm{m})$ \\
\hline & 1.609 & kilometer $(\mathrm{km})$ \\
\hline acre & Area & \\
square mile $\left(\mathrm{mi}^{2}\right)$ & 4,047 & square meter $\left(\mathrm{m}^{2}\right)$ \\
\hline & 2.590 & square kilometer $\left(\mathrm{km}^{2}\right)$ \\
\hline acre-foot (acre-ft) & Volume & \\
\hline & 1,233 & cubic meter $\left(\mathrm{m}^{3}\right)$ \\
\hline cubic foot per second $\left(\mathrm{ft}^{3} / \mathrm{s}\right)$ & Flow rate & \\
\hline & 0.02832 & cubic meter per second $\left(\mathrm{m}^{3} / \mathrm{s}\right)$ \\
\hline ton per year (ton $/ \mathrm{yr})$ & Mass & \\
\hline
\end{tabular}

Vertical coordinate information is referenced to the National Geodetic Vertical Datum of 1929 (NGVD 29).

Horizontal coordinate information is referenced to the North American Datum of 1983 (NAD 83).

Land-surface altitude (LSA), as used in this report, refers to distance above the vertical datum. 


\title{
Precipitation and Streamflow Data from the Fort Carson Military Reservation and Precipitation, Streamflow, and Suspended-Sediment Data from the Piñon Canyon Maneuver Site, Southeastern Colorado, 2008-2012
}

\author{
By Christopher R. Brown
}

\begin{abstract}
In 2013, the U.S. Geological Survey (USGS), in cooperation with the U. S. Department of the Army, compiled available precipitation and streamflow data for the years of 2008-2012 from the Fort Carson Military Reservation (Fort Carson) near Colorado Springs, Colo., and precipitation, streamflow, and suspended-sediment loads from the Piñon Canyon Maneuver Site (PCMS) near Trinidad, Colo. Graphical representations of the data presented herein are a continuation of work completed by the USGS in 2008 to gain a better understanding of spatial and temporal trends within the hydrologic data.

Precipitation stations at Fort Carson and the PCMS were divided into groups based on their landsurface altitude (LSA) to determine if there is a spatial difference in precipitation amounts based on LSA for either military facility. Two-sample t-tests and Wilcoxon rank-sum tests indicated statistically significant differences exist between precipitation values at different groups for Fort Carson but not for the PCMS. All five precipitation stations at Fort Carson exhibit a decrease in median daily total precipitation from years 2002-2007 to 2008-2012. For the PCMS, median precipitation values decreased from the first study period to the second for the 13 stations monitored year-round except for Burson and Big Hills.

Mean streamflow for 2008-2012 is less than mean streamflow for 1983-2007 for all streamgaging stations at Fort Carson and at the PCMS. During the study period, each of the stream-gaging stations within the tributary channels at the PCMS accounted for less than three percent of the total streamflow at the Purgatoire River at Rock Crossing gage. Peak streamflow for 2008-2012 is less than peak streamflow for 2002-2007 at both Fort Carson and the PCMS. At the PCMS, mean suspendedsediment yield for 2008-2012 increased by 54 percent in comparison to the mean yield for 2002-2007. This increase is likely related to the destruction of groundcover by a series of wildfires within the PCMS in 2008 and 2011.
\end{abstract}

\section{Introduction}

The Fort Carson Military Reservation (Fort Carson) and the Piñon Canyon Maneuver Site (PCMS) are military facilities in southern Colorado that are operated by the U.S. Department of the Army. The U.S. Geological Survey (USGS) installed congressionally-mandated monitoring networks to monitor important surface-water resources at Fort Carson and to assess the impact of military maneuvers on streamflow and suspended-sediment loads at the PCMS (von Guerard, 1993). These networks collect precipitation and streamflow data at Fort Carson, and precipitation, streamflow, and 
suspended-sediment load data at the PCMS. In 2013, the USGS, in cooperation with the U.S. Department of the Army, began an assessment of the available precipitation, streamflow, and suspended-sediment load data from Fort Carson and the PCMS for the years 2008 through 2012.

\section{Purpose and Scope}

The purpose of this report is to present hydrologic data collected at Fort Carson and the PCMS, describe temporal and spatial variations in precipitation, streamflow, and suspended-sediment load, and provide cooperators with data collected within the Fort Carson and PCMS hydrologic networks for the period of 2008-2012.

The scope of this report is limited to the analysis of existing USGS hydrologic data collected from 2008 through 2012 at Fort Carson and the PCMS. Although this report concentrates on the 20082012 time period, recent data are compared to historical values to better understand temporal variations.

\section{Description of Study Area}

The data presented in this report were collected at two geographically distinct study areas used by the U.S. Department of the Army. Both Fort Carson and the PCMS are located on the border of the Great Plains and the Southern Colorado Rocky Mountains physiographic provinces (Fenneman and Johnson, 1946).

\section{Fort Carson Military Reservation}

Fort Carson encompasses approximately 215 square miles $\left(\mathrm{mi}^{2}\right)$ adjacent to and south of the Colorado Springs metropolitan area in El Paso County, Colorado (fig. 1). This military reservation provides residential, training, and maneuver areas for active and reserve units of the U.S. Army. Altitudes at Fort Carson range from about 5,400 to 6,900 feet ( $\mathrm{ft}$ ). The topography of the northern and eastern portions of the study area are characterized by dissected plains and terraces, while the western portion is characterized by deep canyons, hills, and hogbacks of uplifted sedimentary rocks (Leonard, 1984). Fort Carson is within the Upper Arkansas River drainage; northern and eastern portions of the study area are drained by Rock Creek and tributaries of Fountain Creek. The south-central portion is drained by Turkey Creek, and the southwestern portion is drained by Red Creek and other tributaries of Beaver Creek. The USGS operates a network of 5 precipitation stations and 15 stream-gaging stations installed in the vicinity of Fort Carson to collect hydrologic data (fig. 1; table 1).

\section{Piñon Canyon Maneuver Site}

The PCMS is in Las Animas County, about 25 miles northeast of Trinidad, Colo. (fig. 2). PCMS encompasses approximately $369 \mathrm{mi}^{2}$ of rangeland and canyons, providing multiple training areas for various types of military maneuvers. Altitudes at the PCMS range from about 4,300 to about 5,900 ft. The vast majority of the PCMS drains south and east through incised valleys created by tributaries of the Purgatoire River (von Guerard and others, 1987). The USGS operates a network of 18 precipitation stations, 18 stream-gaging stations, and 5 suspended-sediment monitoring stations in the PCMS (fig. 2; table 2).

\section{Previous USGS Investigations}

Although hydrologic data collection by the USGS has been ongoing, in some capacity, at Fort Carson since 1978 and at the PCMS since 1983, a limited number of USGS reports have been published analyzing data from the two data-collection networks. Other organizations (U.S. Department of the 
Army, U.S. Department of Agriculture, and U.S. Army Corps of Engineers) have conducted research and data collection at Fort Carson and the PCMS but this section concentrates on the scientific investigations conducted by the USGS.

\section{Fort Carson Investigations}

Jenkins (1971) reported results from pumping tests performed at the Stroebel Spring sump, located near the headwaters of Turkey Creek, as part of a supplementary study of the proposed Fort Carson Expansion Project. The rate of groundwater inflow to the sump was determined to establish a sustainable groundwater withdrawal rate from the Turkey Creek alluvium.

Edelmann (1984) studied the effects of irrigating the golf course at Fort Carson with treated wastewater. Groundwater quality was analyzed for samples collected at 20 observation wells in and around the golf course. Estimates of transmissivity within the shallow alluvial aquifer system were calculated from aquifer test results.

Leonard (1984) provided the U.S. Army with the information necessary to facilitate long-range water-resource planning and management for Fort Carson. This was achieved by reporting water quality and quantity information for surface-water and groundwater resources within the boundaries of Fort Carson.

\section{PCMS Investigations}

Von Guerard and others (1987) conducted a multidisciplined hydrologic investigation to describe the hydrology of the PCMS. The study synthesized data from spring and well inventory, waterquality sampling, stream-gaging, suspended-sediment calculations, and storage capacity calculations to give a synoptic view of the hydrologic setting at the PCMS.

Von Guerard and others (1993) assessed the effects of military maneuvers at the PCMS on streamflow, water quality, and suspended-sediment yields. There was no significant difference in streamflow or water quality that could be attributed to military maneuvers, however, sediment yields decreased in six of the seven drainage basins within the PCMS due to offsets brought about by improved ground cover and management practices (von Guerard and others, 1993).

Stephens and others (2008) illustrated temporal and spatial variations in precipitation, streamflow, suspended-sediment load and yields, and land-condition trend analyses at the PCMS for 1983-2007. Results indicate that runoff from larger, less frequent precipitation events were responsible for the majority of suspended-sediment transport through the arroyos within the PCMS, and that areas with no vehicular, mechanized training exhibited less disturbed and bare ground.

\section{Methods}

This section of the report describes how data and samples were collected at Fort Carson and the PCMS, and how data were analyzed for hydrologic interpretation. Data were collected from 2008 through 2012 at 23 precipitation stations; streamflow data were collected at 33 stations; and suspendedsediment data were collected at 5 tributary stations. For the purpose of consistency and brevity, the short names for precipitation, stream-gaging, and suspended-sediment stations will be used (tables 1 and 2). The short-name convention for the PCMS stations is the same used by Stevens and others (2008), where applicable. 


\section{Data Collection}

Precipitation data were collected for five stations monitored year-round at Fort Carson (fig. 1, table 1). At the PCMS, precipitation data were collected for 18 stations (fig. 2, table 2): 13 monitored year-round, and 5 monitored seasonally from April to October. All precipitation-monitoring stations used for this study were 8- to 12-inch tipping-bucket gages, and were regularly visited and maintained. During each warm weather visit, calibration checks were made to cover the range of historical precipitation intensities (Stevens and others, 2008).

Streamflow data were collected for 15 stations at Fort Carson (fig. 1, table 1): 14 stations are monitored year-round, and one station (Red) is monitored for peak flow only. At the PCMS, streamflow data were collected at 18 stations (fig. 2, table 2): 7 stations are monitored year-round, and 11 stations (Unnamed Trib, Lockwood Arroyo, West Lockwood, South Big, North Lockwood, Middle Bear, West Bear, East Bear, Big Arroyo, Van Bremer Thatcher, and Van Bremer Tyrone) are monitored for peak flow only. Manual streamflow measurements were made approximately monthly at all stream-gaging stations with a current-meter according to procedures described in Buchanan and Somers (1969). These measurements were used to compute and analyze the continuous streamflow data from the monitoring stations according to procedures described in Kennedy (1983) and Turnipseed and Sauer (2010).

Suspended-sediment load data were collected at five tributary stream-gaging stations at the PCMS (fig. 2; table 2). The explanation of the suspended-sediment sample-collection method is taken directly from Stephens and others (2008). Suspended-sediment data were collected during storm runoff by using automated sediment samplers. In general, the satellite data-collection recorder activated the automated sediment sampler when a predetermined rate of stage change in the stream was exceeded or when a predetermined time interval was exceeded. When possible, depth- and width-integrated suspended-sediment samples (Edwards and Glysson, 1988) were collected at stream-gaging stations to define temporal or flow-related coefficients (or adjustments) between the depth- and width-integrated concentration and the automated sediment-sample concentration. The depth- and width-integrated sample was considered representative of all suspended sediment in the channel. Automated sediment samplers were installed with a single-point intake to collect sediment from the suspended fraction of the water column. The automated sediment sample, which represents the concentration at the sampler intake point, can be adjusted with a coefficient that is expressed as a percentage of the depth- and widthintegrated concentration. Due to the remoteness of the PCMS stations and the inability to collect frequent depth- and width-integrated samples and to determine a long-term temporal or flow-related relation, the depth- and width-integrated and point-sample relations were not used in sediment-discharge computations. However, those relations were used in assessing possible error in defining the crosssectional sediment concentrations with the automated samples. Only a few suspended-sediment samples were analyzed for size fractions.

The precipitation, streamflow, and suspended-sediment data from this study are stored in the USGS National Water Information System (NWIS; http://waterdata.usgs.gov/co/nwis/inventory, accessed March 2013). Quality assurance protocols were implemented for precipitation, streamflow, and suspended-sediment data collection. Precipitation data-collection methods were conducted in accordance with procedures issued by the Office of Surface Water (U.S. Geological Survey, 2009). Quality assurance for streamflow data-collection methods were based on procedures outlined in Turnipseed and Sauer (2010). The sediment data-collection program is in accordance with procedures included in Rasmussen and others (2009). Daily precipitation, streamflow, and sediment data met acceptable protocol for publication in the annual USGS Water-Data Reports (http://wdr.water.usgs.gov/). 


\section{Hydrologic Data}

The following section describes the temporal variation in data collected within Fort Carson and the PCMS hydrologic data-collection networks from 2008 to 2012. Historical values for annual mean streamflow, annual peak streamflow, and precipitation are presented for both data networks.

\section{Fort Carson Hydrologic Data 2008-2012}

The Fort Carson hydrologic-data-collection network consists of five precipitation stations with land-surface altitudes (LSA) ranging from 5,350 ft to 6,120 ft above the National Geodetic Vertical Datum of 1929 (NGVD 29), and 15 stream-gaging stations located in streams, tributaries, and diversions around Fort Carson (table 1).

\section{Fort Carson Precipitation}

The majority of precipitation at Fort Carson is in the form of monsoonal activity in the months of July, August, and September, with supplementary spring showers (fig. 3). To determine if there is a spatial difference in precipitation amounts based on LSA, the precipitation stations were divided into groups based on LSA. The stations were divided so that there were a similar number of stations in each category: stations with LSA of 5,300-5,800 ft and stations with LSA greater than 5,800 ft (fig. 4a).

Annual median precipitation values for the two LSA groups were plotted for a 10-year period beginning in 2002, which is when the frequency of data collection for all five stations was consistent. A pooled-variance two-sample t-test and a Wilcoxon rank-sum test (both with confidence intervals of 95 percent; Helsel and Hirsch, 2002) were used to compare precipitation values of the two groups. There is a statistically significant difference in annual precipitation between the two groups of precipitation: for the t-test, the t-statistic with 51 degrees of freedom is $[\mathrm{t}(51)]=-2.18, \mathrm{p}=0.03$, two-tailed; and for the Wilcoxin rank-sum test, the $\mathrm{z}$-score is $[\mathrm{Z}]=-2.10, \mathrm{p}=0.035$. Precipitation values for the two groups of precipitation stations were plotted against one another, and a simple linear regression was used to discern any relation between the datasets (fig. 4b). The calculated regression line (coefficient of determination $\left.\left[\mathrm{r}^{2}\right]=0.90\right)$ indicates higher precipitation values at greater than $5,800 \mathrm{ft}$ LSA compared to the other group of stations $(5,300-5,800 \mathrm{ft}$ LSA).

Boxplots provide useful and concise graphical summaries of essential dataset characteristics; they are powerful for side-by-side comparisons of different groups of data (Helsel and Hirsch, 2002). Precipitation values for the years 2002-2007 were compared with values from the years 2008-2012 (fig. 5). Only non-zero values of daily total precipitation were used in this analysis, and the plots were truncated at the 10th and 90th percentile to eliminate outliers. Truncation allows values falling within the interquartile range (IQR) to be more easily evaluated. All five precipitation stations exhibit a decrease in median daily total precipitation from the first study period (2002-2007) to the second study period (2008-2012). With the exception of the Range 111 station, all stations show a decrease in the upper bound of the IQR and a decrease in the 90th percentile from the first to the second study period (fig. 5).

\section{Fort Carson Streamflow}

Turkey Creek near Fountain (USGS site number 07099215; Turkey Fountain), Turkey Creek above Teller Reservoir (USGS site number 07099230; Turkey Teller), Turkey Creek near Stone City (USGS site number 07099235; Turkey Stone), and Rock Creek above Fort Carson (USGS site number 07105945; Rock) stream-gaging stations have been monitored since 1979. The entire period of record for these gages is plotted to illustrate temporal changes although the focus of this report is the years 
2008-2012 (figs. 6-9). Turkey Fountain and Turkey Teller have exhibited annual mean streamflow values of near zero since 2000, but with more year-to-year streamflow variation prior to 2000. Annual mean streamflow at Turkey Stone has decreased since 1997 to values near zero, similar to Turkey Fountain and Turkey Teller. In contrast, annual mean streamflow at the Rock gage has exhibited more scatter than gages on Turkey Creek; mean annual streamflow at the Rock gage has decreased from 4 cubic foot per second $\left(\mathrm{ft}^{3} / \mathrm{s}\right)$ for 1979-2007 to less than $1 \mathrm{ft}^{3} / \mathrm{s}$ for the current study period (2008-2012).

Red Creek below Sullivan Park (USGS station number 07099080; Red) is monitored only for annual peak streamflow (fig. 10). Mean peak streamflow from 2002-2007 is $966 \mathrm{ft}^{3} / \mathrm{s}$, whereas the mean peak streamflow for 2008-2012 is $383 \mathrm{ft}^{3} / \mathrm{s}$. The marked difference between the mean peak streamflow for these two periods of record can be attributed to two flood events that occurred in 2003 and 2006 (fig. 10).

There is a series of surface-water diversions along Rock Creek and Turkey Creek with streamgaging stations installed on-site (table 1; fig. 1). Womack Ditch, Gale Ditch, Merriam's Rock Creek Ditch, and Strobel Ditch have been monitored since 1999, whereas Ripley Ditch, Merriam's Little Fountain Ditch, and Lytle Ditch have been monitored since 2003. All the diversions have exhibited annual mean streamflow values of less than $1 \mathrm{ft}^{3} / \mathrm{s}$ for the study period, 2008-2012, with the exception of the annual mean values for 2009 at Merriam's Rock Creek, Ripley, and Womack. Turkey Creek West had annual mean streamflow values of zero $\mathrm{ft}^{3} / \mathrm{s}$ from 2001 to the end of the study period.

\section{PCMS Hydrologic Data 2008-2012}

The PCMS hydrologic-data-collection network consists of 18 precipitation stations with LSA's ranging from 4,402 ft to 5,630 ft above NGVD 29, and 18 stream-gaging stations located on the Purgatoire River and its tributaries (table 2). Five of the 18 stream-gaging stations are equipped with suspended-sediment monitoring equipment.

\section{PCMS Precipitation}

About 80 percent of the total annual precipitation at the PCMS occurs as rain from March through October (von Guerard and others, 1987). For the PCMS network, as with Fort Carson, the majority of precipitation comes in the form of monsoonal activity in the months of July, August, and September, with supplementary spring showers (figs. 11 and 12). The same analysis that was applied to the Fort Carson data was performed on the PCMS data to determine if there is a spatial difference in precipitation amounts based on LSA. The year-round stations were divided so that there were a similar number of stations in each category: stations with LSA of 4,700-5,000 ft, stations with LSA of $>5,000$ $5,300 \mathrm{ft}$, and stations with LSA greater than 5,300 ft (fig. 13a).

Annual median precipitation values for the three groups of stations were plotted for a 10-year period beginning in 2002 (fig. 13a). Precipitation values for the two groups with lower LSA $(4,700$ $5,000 \mathrm{ft}$ and $>5,000-5,300 \mathrm{ft}$ ) were averaged and compared to values from the group with the highest LSA $(>5,300 \mathrm{ft})$ to accentuate differences in precipitation for the highest LSA group. A pooled-variance two-sample t-test and Wilcoxon rank-sum test (both with confidence intervals of 95 percent) were used to compare precipitation values of the two groups. There was not a statistically significant difference in annual precipitation between the two groups of precipitation stations: for the t-test, the t-statistic with 51 degrees of freedom is $[\mathrm{t}(51)]=1.13, \mathrm{p}=0.26$, two-tailed; and for the Wilcoxon rank-sum test , the $\mathrm{z}$ score is $[Z]=0.91, p=0.36$. Precipitation values for the two groups of precipitation stations were plotted against one another, and a simple linear regression was used to discern any relation between the datasets (fig. 13b). The calculated regression line $\left(\mathrm{r}^{2}=0.89\right)$ indicates similar precipitation amounts 
within the groups. It is possible that there is not enough topographic relief on-site to show differences in precipitation amount based on LSA.

Precipitation values for the years 2002-2007 were compared with values from the years 20082012 (figs. 14 and 15). Only non-zero values of daily total precipitation were used in this analysis, and the plots were truncated at the 10th and 90th percentile to eliminate outliers. Median precipitation values decreased from the first to the second study period for all of the 13 stations monitored year-round except for Burson and Big Hills. Five of the 13 stations showed a decrease in both the upper and lower bounds of the IQR between the two study periods, with all stations showing a decrease in the 90th percentile (fig. 14). For seasonally monitored precipitation stations, two (Van Bremer and Taylor) of the five stations showed a decrease in median between the two study periods, while at two (Lockwood Canyon and Bent) of the stations the median values increased. The Bent and Lockwood Canyon stations also exhibited increases in the 10th, 25th, 75th, and 90th percentiles for precipitation value from the first to the second study period (fig. 15).

\section{PCMS Streamflow}

Annual mean streamflow for the entire period of record is plotted, along with a line indicating mean annual streamflow from 1983-2012 for Purgatoire River near Thatcher and Purgatoire River at Rock Crossing (figs. 16 and 17; Stevens and others, 2008). Annual mean streamflow for 2008-2012 is less than mean annual streamflow for 1983-2007 for both of these long-standing stream gages. The PCMS is incised by southeast-trending canyons, providing tributary flow to the Purgatoire River. During the study period, each of the stream-gaging stations within the tributary channels at the PCMS accounted for less than 3 percent of the total streamflow at the Purgatoire River at Rock Crossing gage (fig. 18), concurrent with values presented in Stevens and others (2008).

The five, annually, monitored stream-gaging stations (Van Bremer Model, Taylor, Lockwood Canyon, Red Rock, Bent) and the Big Arroyo gage (monitored for peak flow only) on tributaries of the Purgatoire River record the annual peak flow events entering the Purgatoire River (table 2). Plotting annual peak flow for the period of record shows temporal variability for large precipitation events flowing into the Purgatoire River. Mean peak streamflow from 2008-2012 has decreased slightly when compared to the rest of the period of record from 1983-2007. The mean peak streamflow for 1983-2007 is likely positively skewed by the annual peak event in 1998, which is in the 99.99th percentile of all the annual peak streamflow values (fig. 19).

\section{PCMS Suspended Sediment}

The mobilization and transport of subaerial sediments has been monitored at selected PCMS stations since 1983 and on a regular basis since 2000 at the five stations included in this study (table 2). When analyzing the period from 2002-2012, total suspended-sediment yield for the five seasonally monitored (April 1-October 31) stations at the PCMS ranged from 0.1 ton per acre-foot of streamflow at Taylor to 16.5 tons per acre-foot of streamflow at Red Rock. The mean suspended-sediment yield for 2008-2012 has increased by 54 percent in comparison to the mean yield for 2002-2007 (fig. 20). The increase in suspended-sediment yield is likely related to destruction of groundcover by wildfires in 2008 and 2011, affecting the Lockwood, Red Rock, and Bent drainage areas (Jeffrey C. Linn, U.S. Army, written commun., 2013). Figures 21 through 25 show mean daily streamflow and estimated suspendedsediment load for the five major tributary channels discharging to the Purgatoire River. The relation between precipitation, the primary driver of streamflow, and suspended-sediment load is unclear; limited data make short-term trends difficult to interpret (Stevens and others, 2008). 


\section{Summary}

In 2013, the USGS, in cooperation with the U. S. Department of the Army, began assessment of the available precipitation, streamflow, and suspended-sediment load data for the years of 2008-2012 from Fort Carson Military Reservation (Fort Carson) and the Piñon Canyon Maneuver Site (PCMS). Graphical representations of the data collected were presented to illustrate temporal and spatial changes within the hydrologic data as a continuation of work completed by Stevens and others in 2008.

For Fort Carson and the PCMS, the majority of precipitation comes in the form of monsoonal activity in the months of July, August, and September, with supplementary spring showers. Precipitation stations were divided into groups based on their land-surface altitude (LSA). Precipitation values were plotted against time and values from other groups to discern if there is a spatial difference in precipitation based on LSA. There was a statistically significant difference in precipitation amounts between station groups at Fort Carson but not at the PCMS. Stations with higher LSA exhibited greater precipitation amounts at Fort Carson but not at the PCMS. It is possible that there is not enough topographic relief at the PCMS to show differences in precipitation amount based on LSA. At Fort Carson, all five precipitation stations exhibit a decrease in median daily total precipitation from the first study period (2002-2007) to the second study period (2008-2012). For the PCMS, median precipitation values decreased from the first to the second study period for all of the 13 stations monitored year-round except for Burson and Big Hills.

Mean streamflow for 2008-2012 is less than mean streamflow for 1983-2007 for all streamflow gages at Fort Carson and at the PCMS. During the study period, each of the stream-gaging stations within the tributary channels at the PCMS accounted for less than 3 percent of the total streamflow at the Purgatoire River at Rock Crossing gage. Peak streamflow for Fort Carson is monitored at the Red gage. Peak streamflow at Red for 2002-2007 is $966 \mathrm{ft}^{3} / \mathrm{s}$, whereas the mean peak flow for 2008-2012 is $383 \mathrm{ft}^{3} / \mathrm{s}$. Peak streamflow is monitored at six seasonal gages at the PCMS. Mean peak streamflow from 2008-2012 has decreased slightly compared to 1983-2007.

Suspended-sediment yield for the PCMS was analyzed for the period of 2002-2012. Total suspended-sediment yield for the five seasonally monitored stations at the PCMS ranged from 0.1 tons per acre-foot of streamflow for 2002-2007 to 16.5 tons per acre-foot of streamflow for 2008-2012. The mean suspended-sediment yield for 2008-2012 has increased by 54 percent in comparison to the mean yield for 2002-2007and is likely related to groundcover destruction by wildfires in 2008 and 2011.

\section{References Cited}

Buchanan, T.J., and Somers, W.P., 1969, Discharge measurements at gaging stations: U.S. Geological Survey Techniques of Water-Resources Investigations, book 3, chap. A8, 65 p.

Edelmann, Patrick, 1984, Effects of irrigating with wastewater on ground-water quality at Fort Carson Military Reservation golf course near Colorado Springs, Colorado: U.S. Geological Survey WaterResources Investigations Report 83-4268, 32 p.

Edwards, T.K., and Glysson, G.D., 1988, Field methods for measurement of fluvial sediment: U.S. Geological Survey Open-File Report 86-531, 117 p.

Fenneman, N.M., and Johnson, D.W., 1946, Physiographic divisions of the conterminous U. S.: U.S. Geological Survey special map series, scale 1:7,000,000.

Helsel, D.R., and Hirsch, R.M., 2002, Statistical methods in water resources: U.S. Geological Survey

Techniques of Water Resources Investigations, book 4, chap. A3, 522 p. 
Jenkins, E.D., 1971, Test of the Stroebel Spring - a supplementary study of the Fort Carson Expansion Project, Civil Action No. 9820, Tract No. 202, El Paso County, Colorado: U.S. Geological Survey Open-File Report 71-157, 20 p.

Kennedy, E.J., 1983, Computation of continuous records of streamflow: U.S. Geological Survey Techniques of Water-Resources Investigations, book 3, chap. A13, 53 p.

Leonard, G.J., 1984, Assessment of water resources at Fort Carson Military Reservation near Colorado Springs, Colorado: U.S. Geological Survey Water-Resources Investigations Report 83-4270, 78 p.

Rasmussen, P.P., Gray, J.R., Glysson, G.D., and Ziegler, A.C., 2009, Guidelines and procedures for computing time-series suspended-sediment concentrations and loads from in-stream turbidity-sensor and streamflow data: U.S. Geological Survey Techniques and Methods, book 3, chap. C4, 53 p.

Stevens, M.R., Dupree, J.A., and Kuzmiak, J.M., 2008, Temporal and spatial variations in precipitation, streamflow, suspended-sediment loads and yields, and land-condition trend analysis at the U.S. Army Piñon Canyon Maneuver Site, Las Animas County, Colorado, 1983 through 2007: U.S. Geological Survey Scientific Investigations Report 2008-5111, 47 p.

Turnipseed, D.P., and Sauer, V.B., 2010, Discharge measurements at gaging stations: U.S. Geological Survey Techniques and Methods, book 3, chap. A8, $87 \mathrm{p}$.

U.S. Geological Survey, 2009, Collection, quality assurance, and presentation of precipitation data: Office of Surface Water Technical Memorandum No. 2006.01, accessed March 2013 at http://water.usgs.gov/admin/memo/SW/sw06.012_Revised_122009.pdf.

von Guerard, P., Abbott, P.O., and Nickless, R.C., 1987, Hydrology of the U.S. Army Piñon Canyon Maneuver Site, Las Animas County, Colorado: U.S. Geological Survey Water-Resources Investigations Report 87-4227, $117 \mathrm{p}$.

von Guerard, P., Parker, R.S., and Dash, R.G., 1993, Assessment of effects of military maneuvers on the streamflow yields at the U.S. Army Piñon Canyon Maneuver Site, Las Animas County, Colorado: U.S. Geological Survey Water-Resources Investigations Report 91-4095, 84 p. 


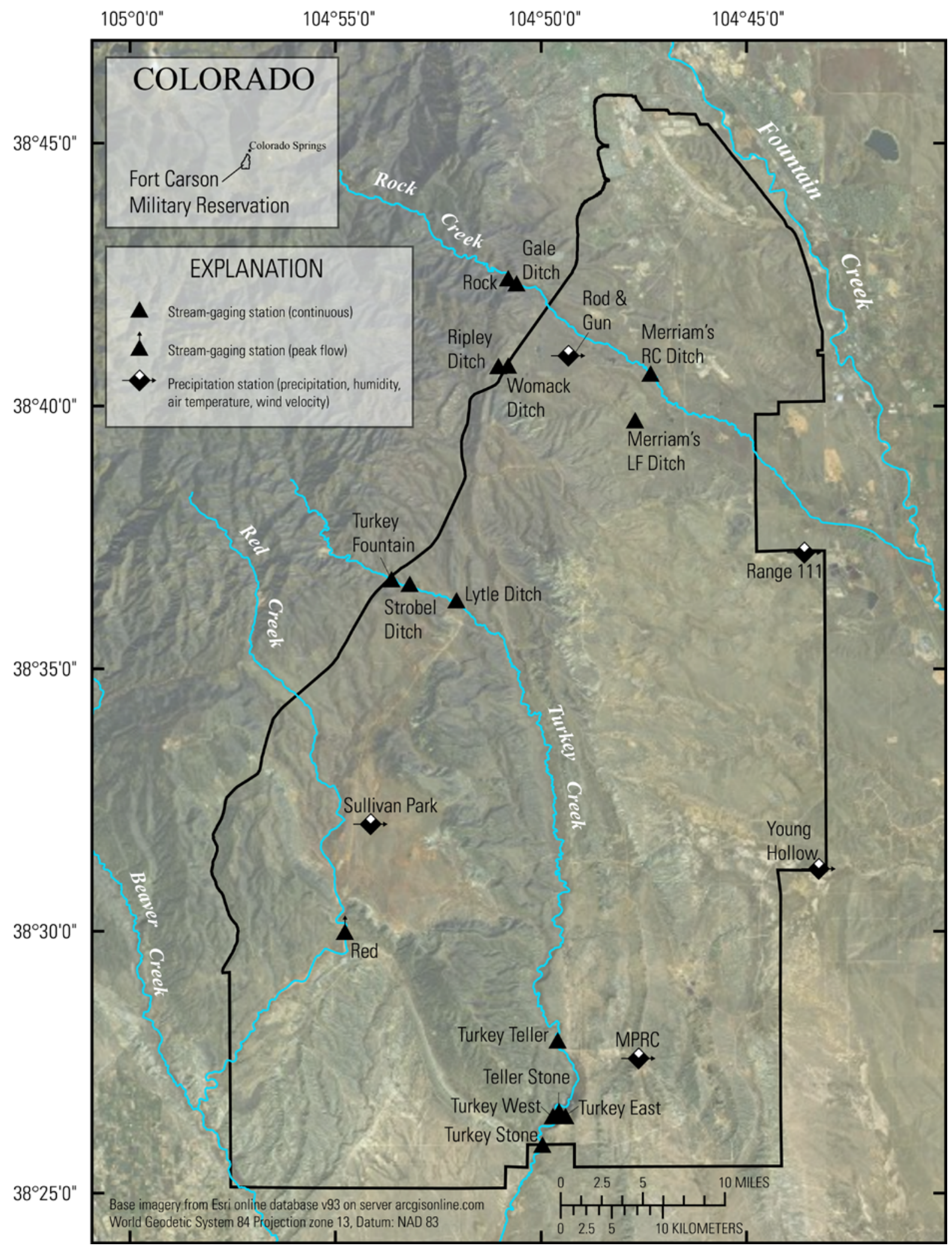

Figure 1. Location of precipitation and stream-gaging stations included in this study at the Fort Carson Military Reservation. 


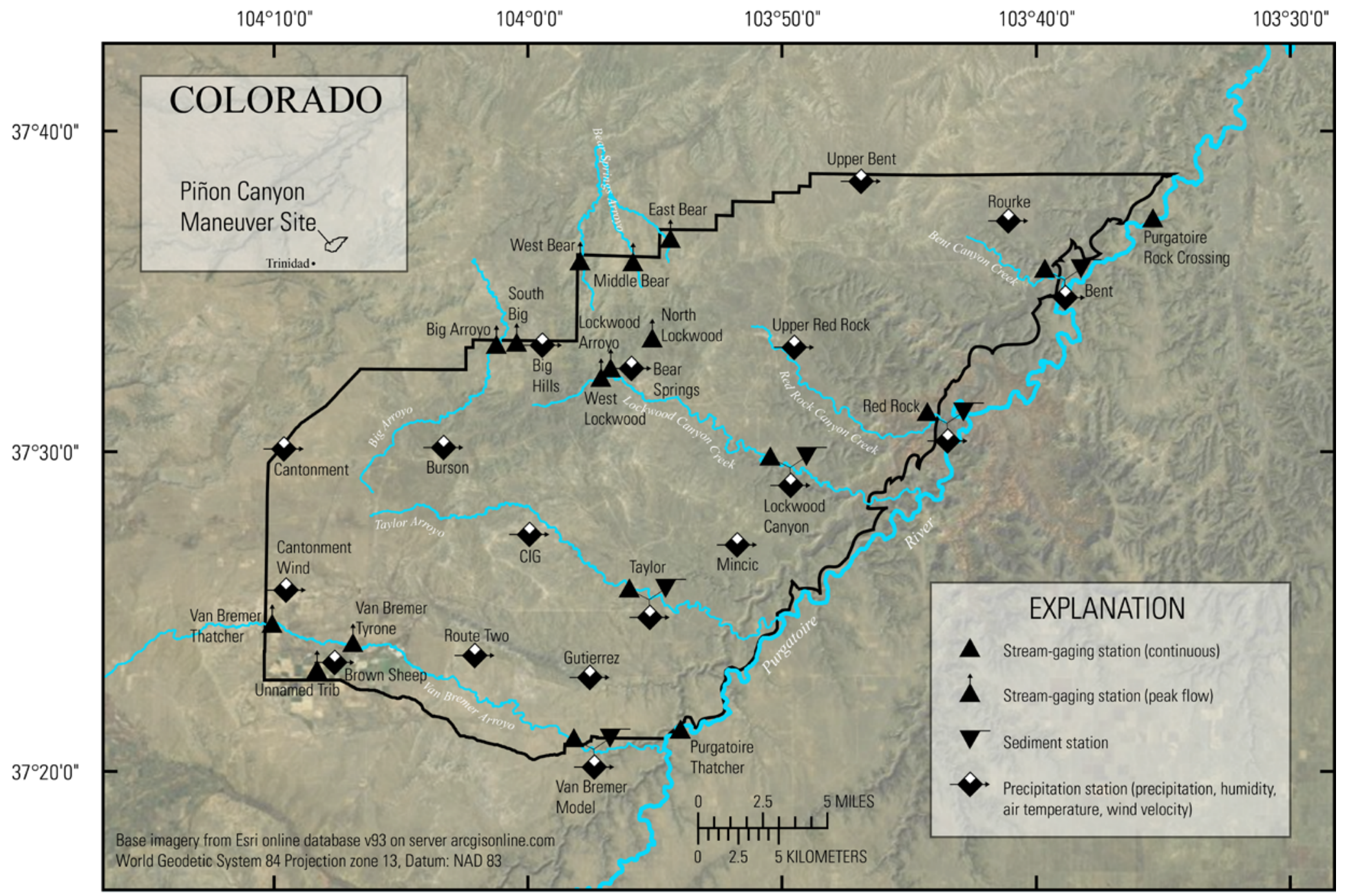

Figure 2. Location of precipitation, stream-gaging, and sediment stations included in this study at the Piñon Canyon Maneuver Site. 


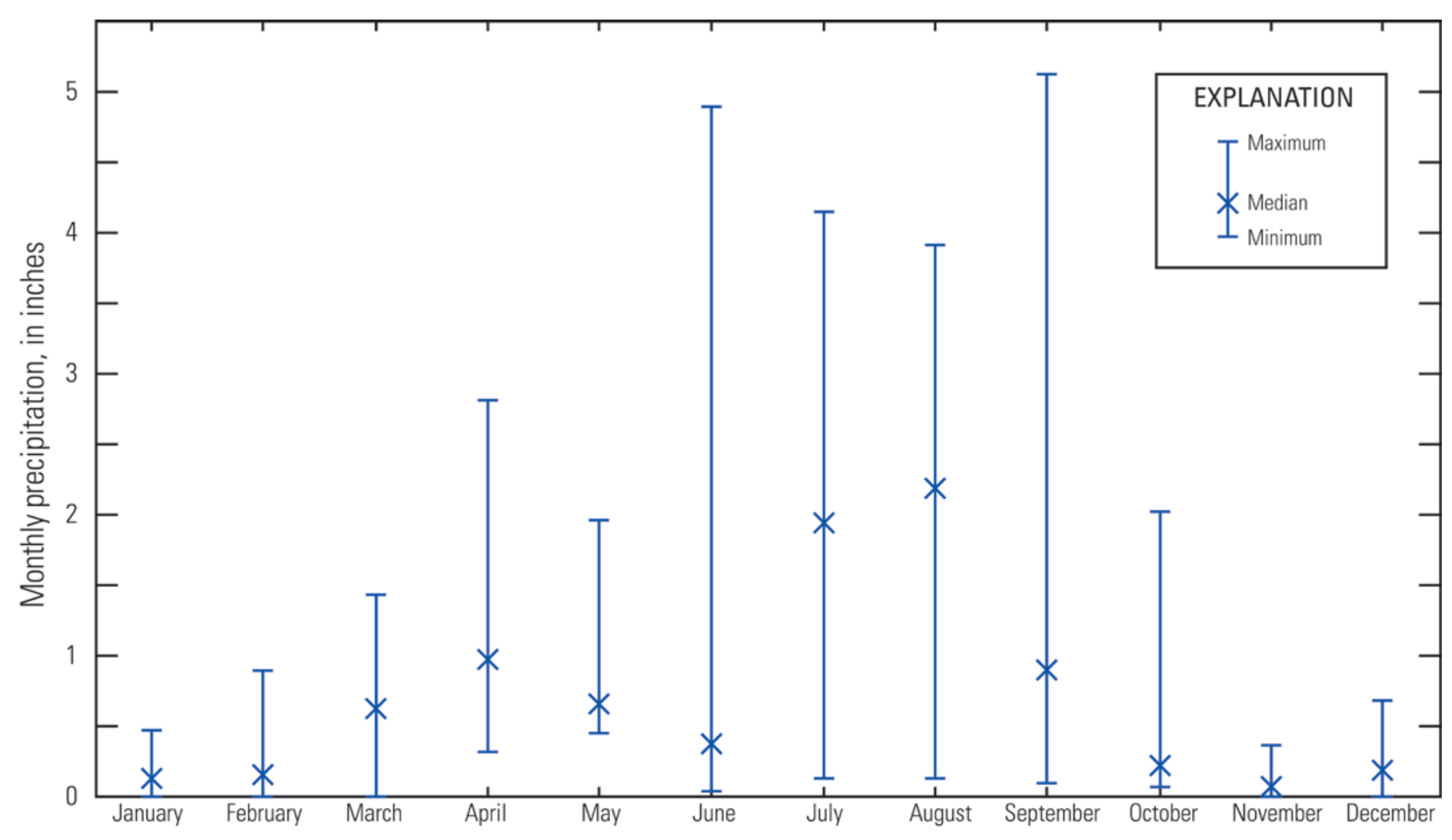

Figure 3. Maximum, minimum, and median monthly precipitation for Fort Carson Military Reservation precipitation stations, 2008-2012. 


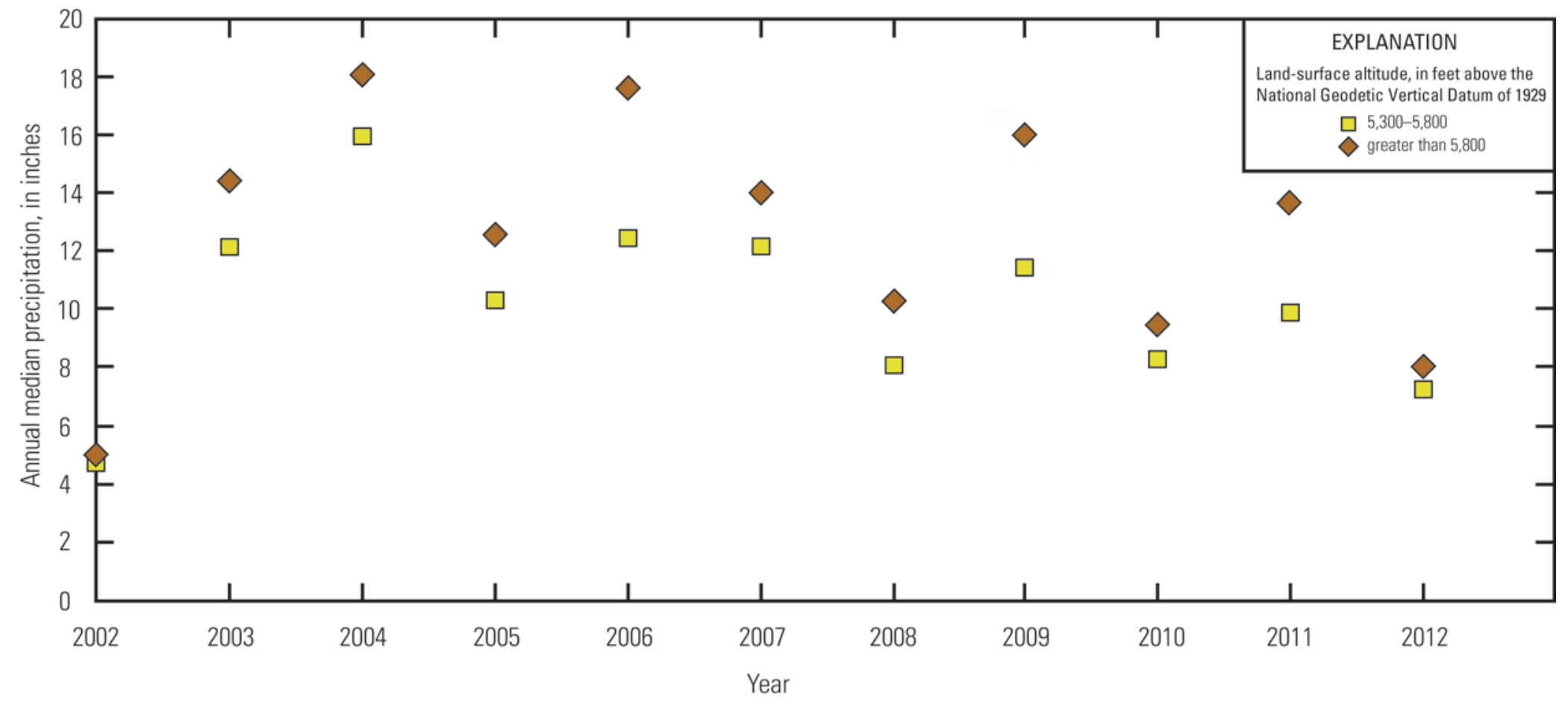

Figure 4. A. Annual median precipitation by land-surface altitude (LSA) for the Fort Carson Military Reservation, $2002-2012$. 


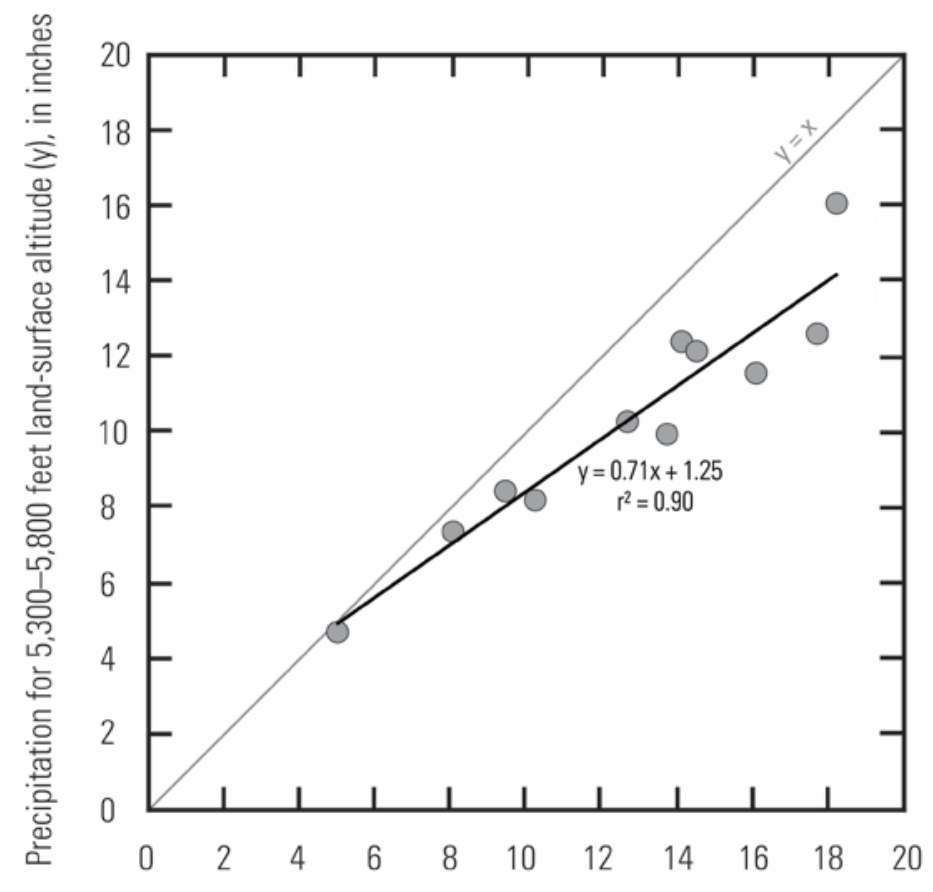

Precipitation for greater than 5,800 feet land-surface altitude $(x)$, in inches

Figure 4. B. Comparison of precipitation amounts between different land-surface altitude (LSA) groups for the Fort Carson Military Reservation, 2002-2012. 


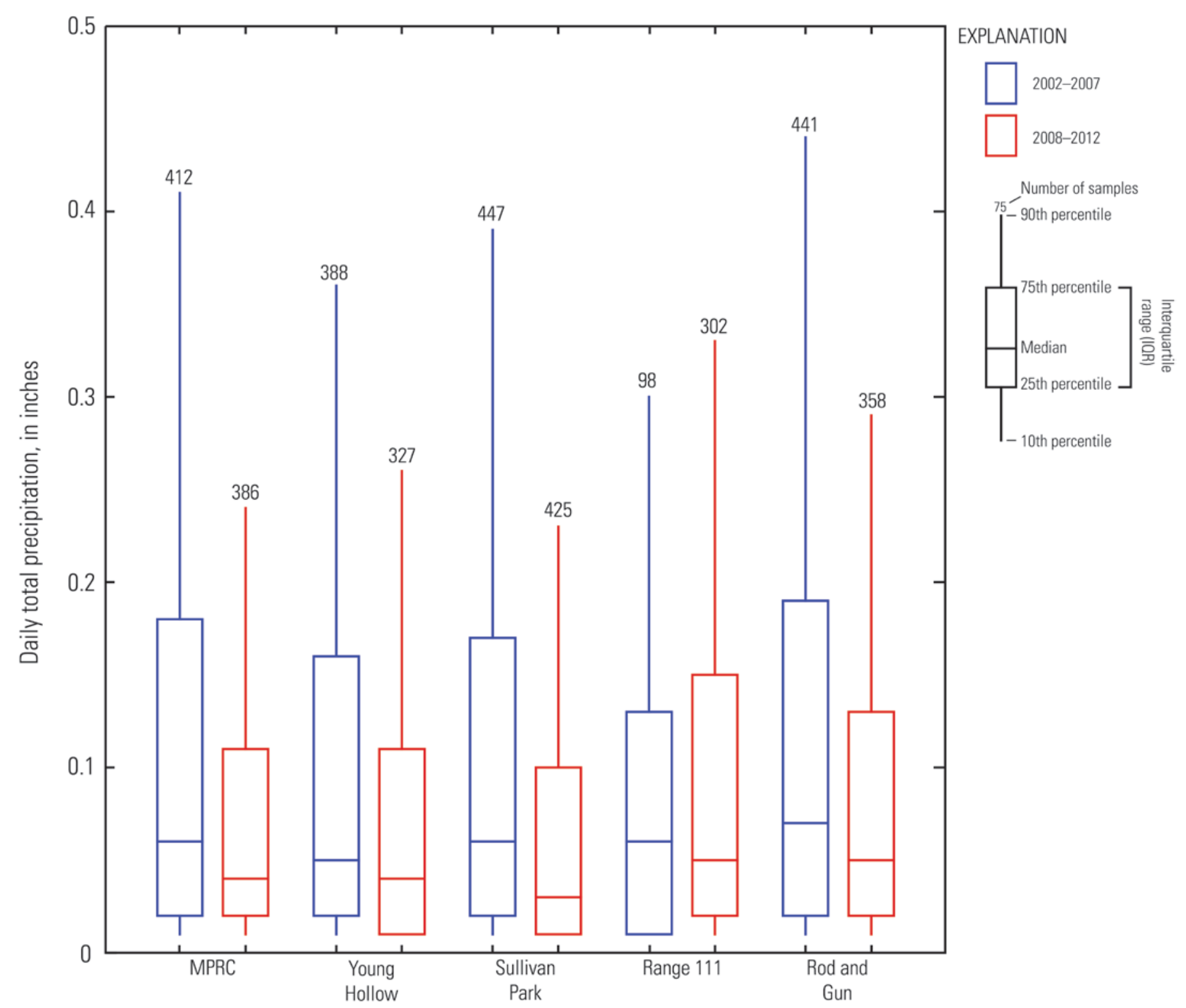

Figure 5. Censored and truncated box plots showing daily precipitation values for Fort Carson Military Reservation precipitation stations. Complete station names are in table 1. 


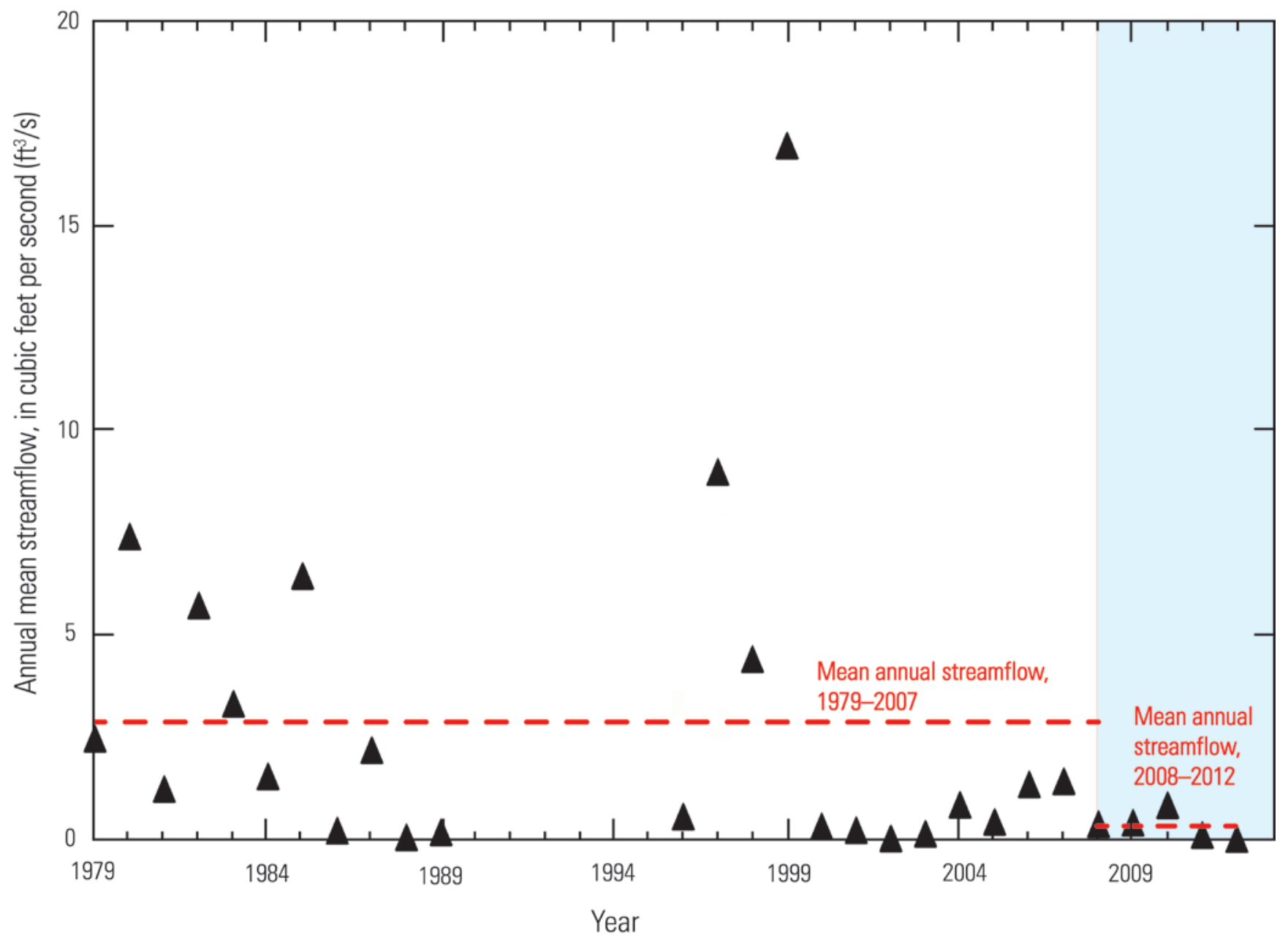

Figure 6. Annual mean streamflow for Turkey Creek near Fountain (USGS site number 07099215, Turkey Fountain). 


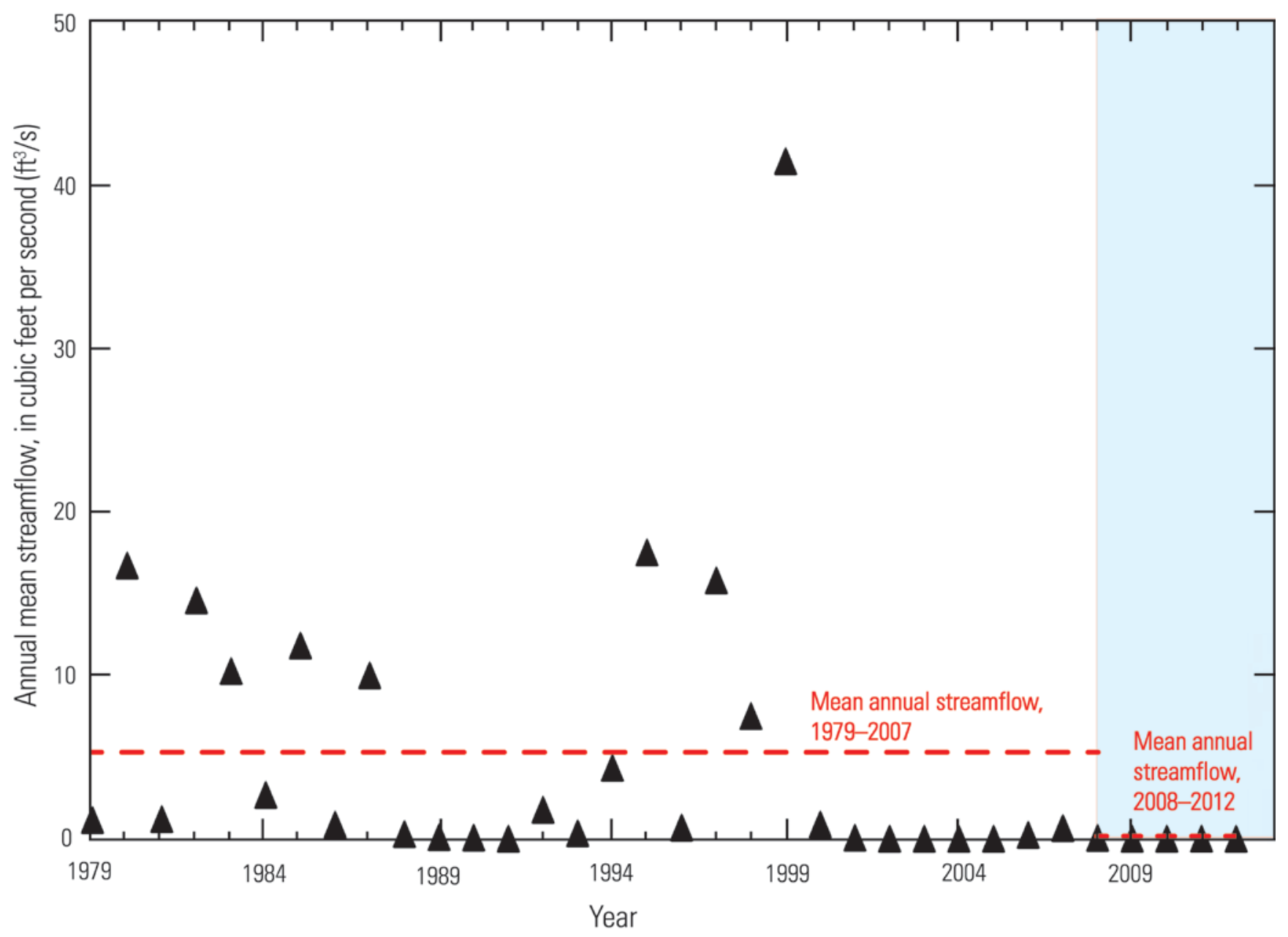

Figure 7. Annual mean streamflow for Turkey Creek above Teller Reservoir (USGS site number 07099230, Turkey Teller). 


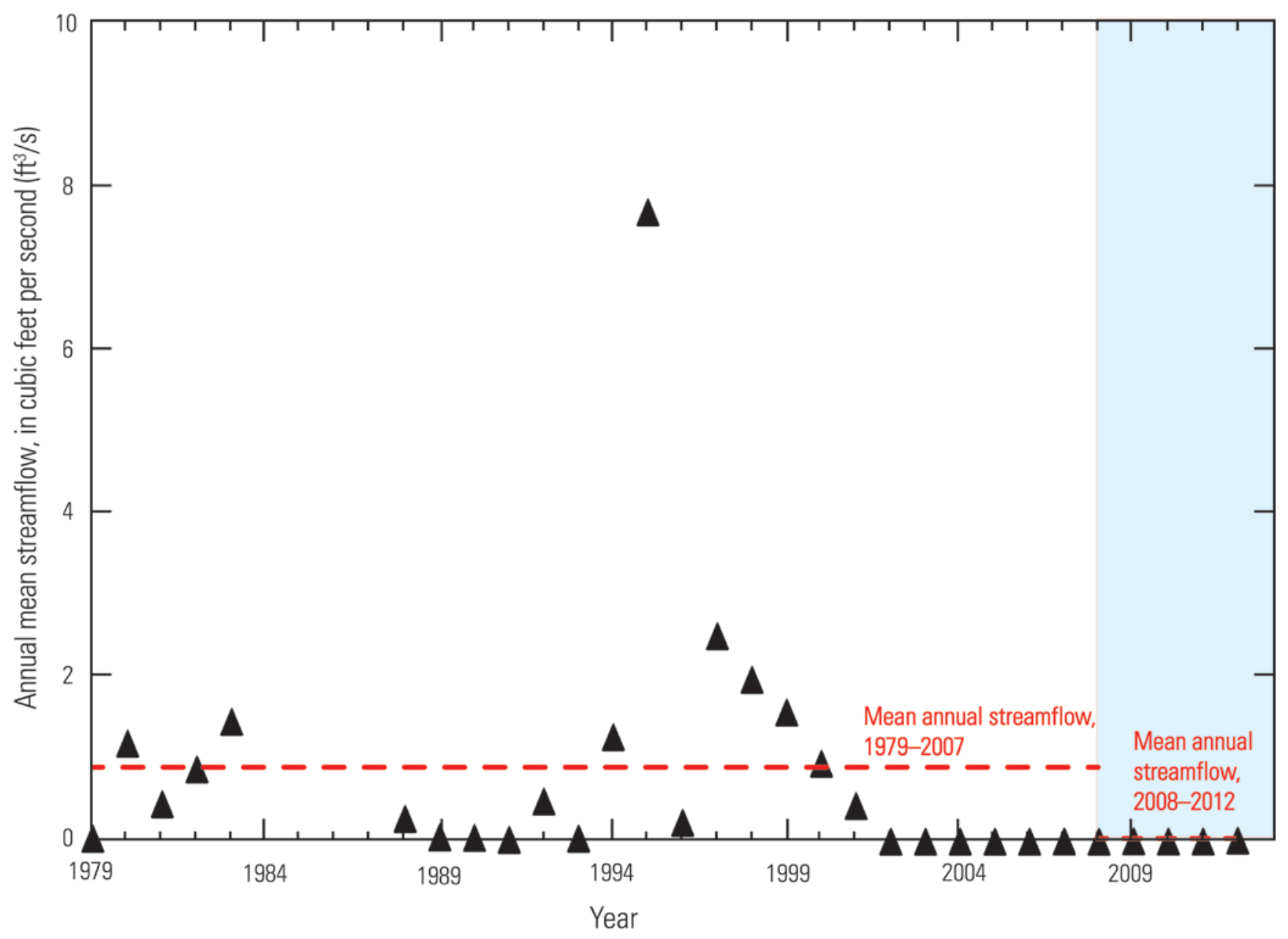

Figure 8. Annual mean streamflow for Turkey Creek near Stone City (USGS site number 07099235, Turkey Stone). 


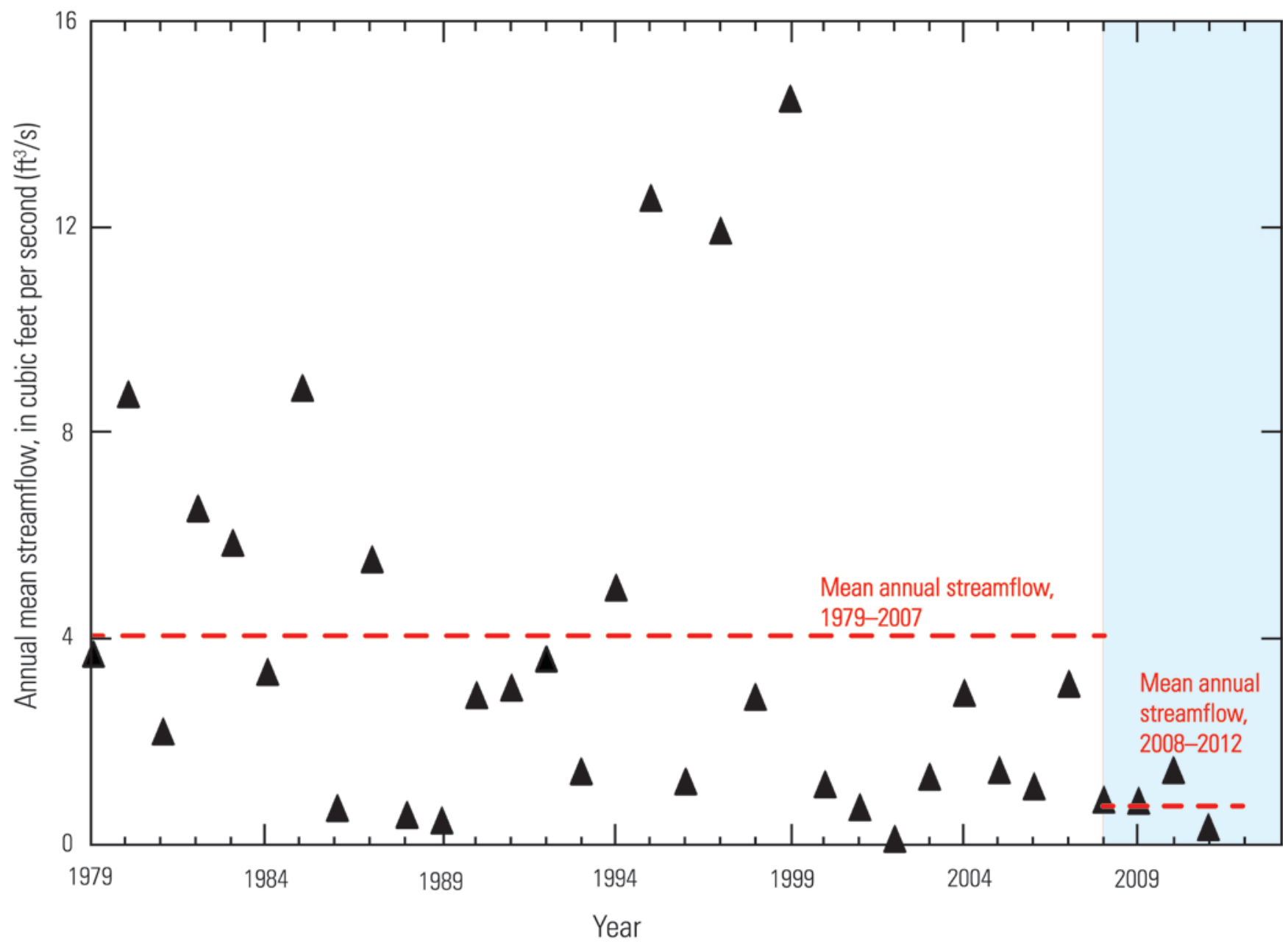

Figure 9. Annual mean streamflow for Rock Creek above Fort Carson (USGS site number 07105945, Rock). 


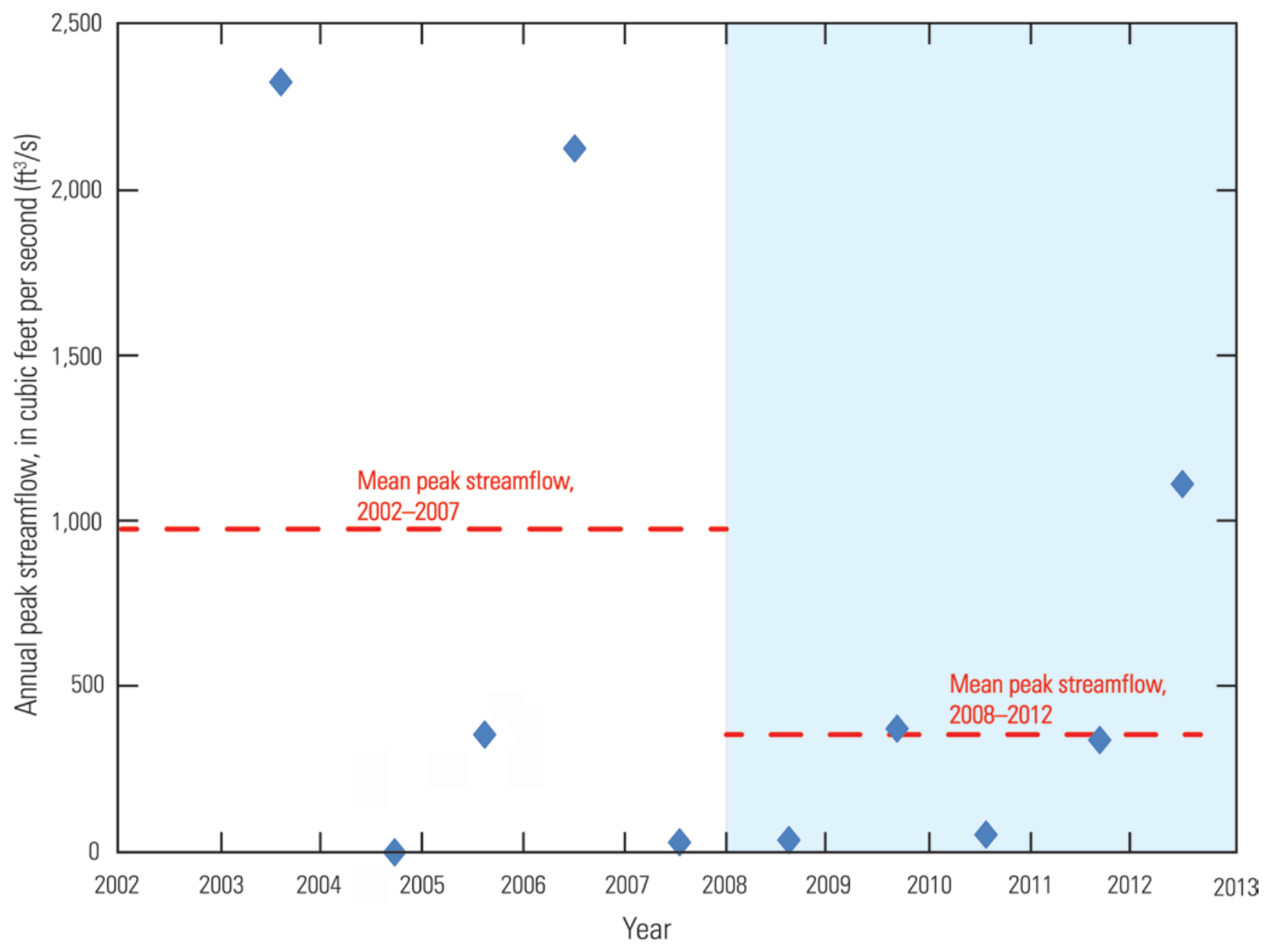

Figure 10. Annual peak streamflow for Red Creek below Sullivan Park (USGS site number 07099080, Red). 


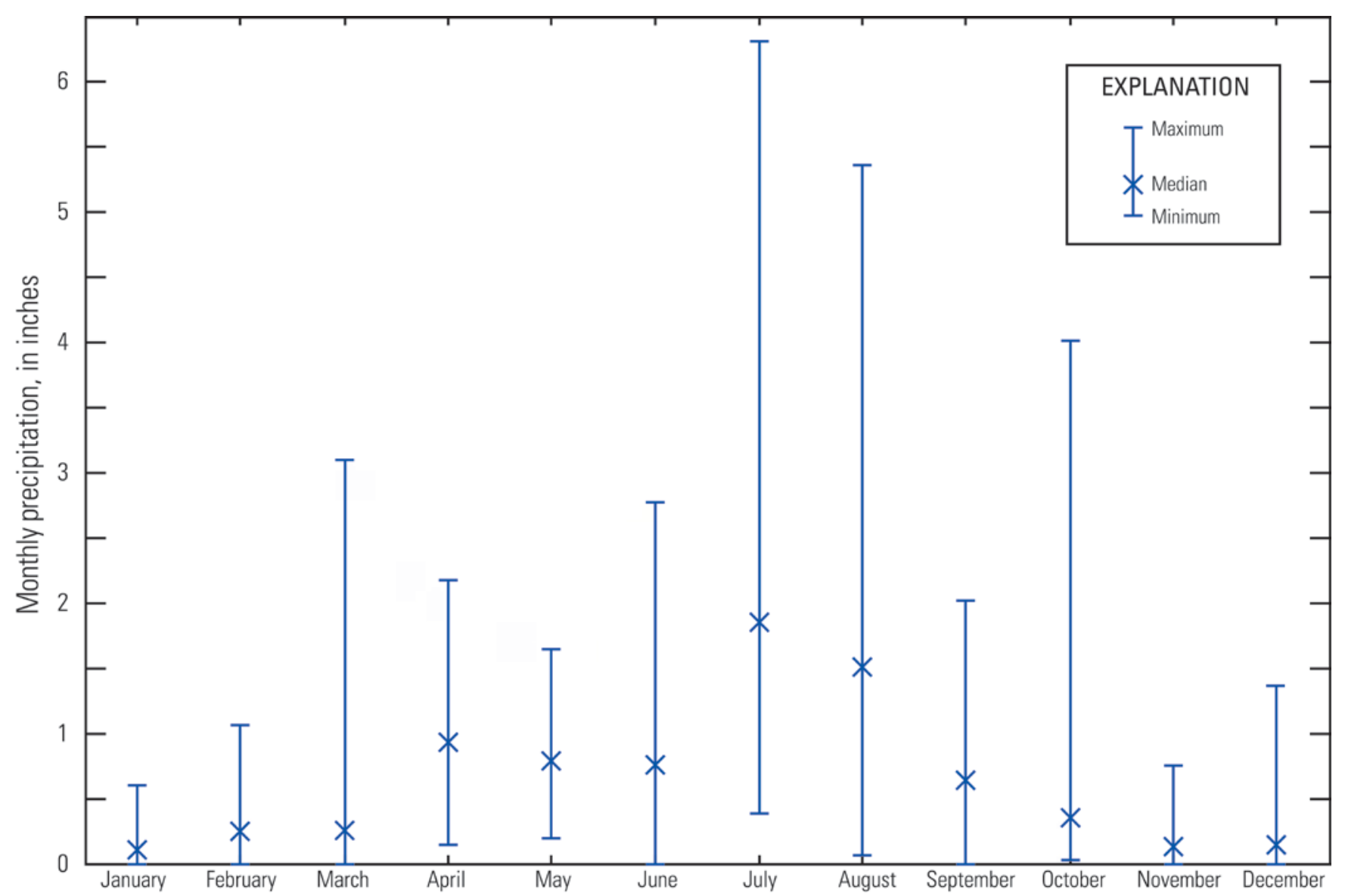

Figure 11. Maximum, minimum, and median monthly precipitation for Piñon Canyon Maneuver Site precipitation stations, 2008-2012. 


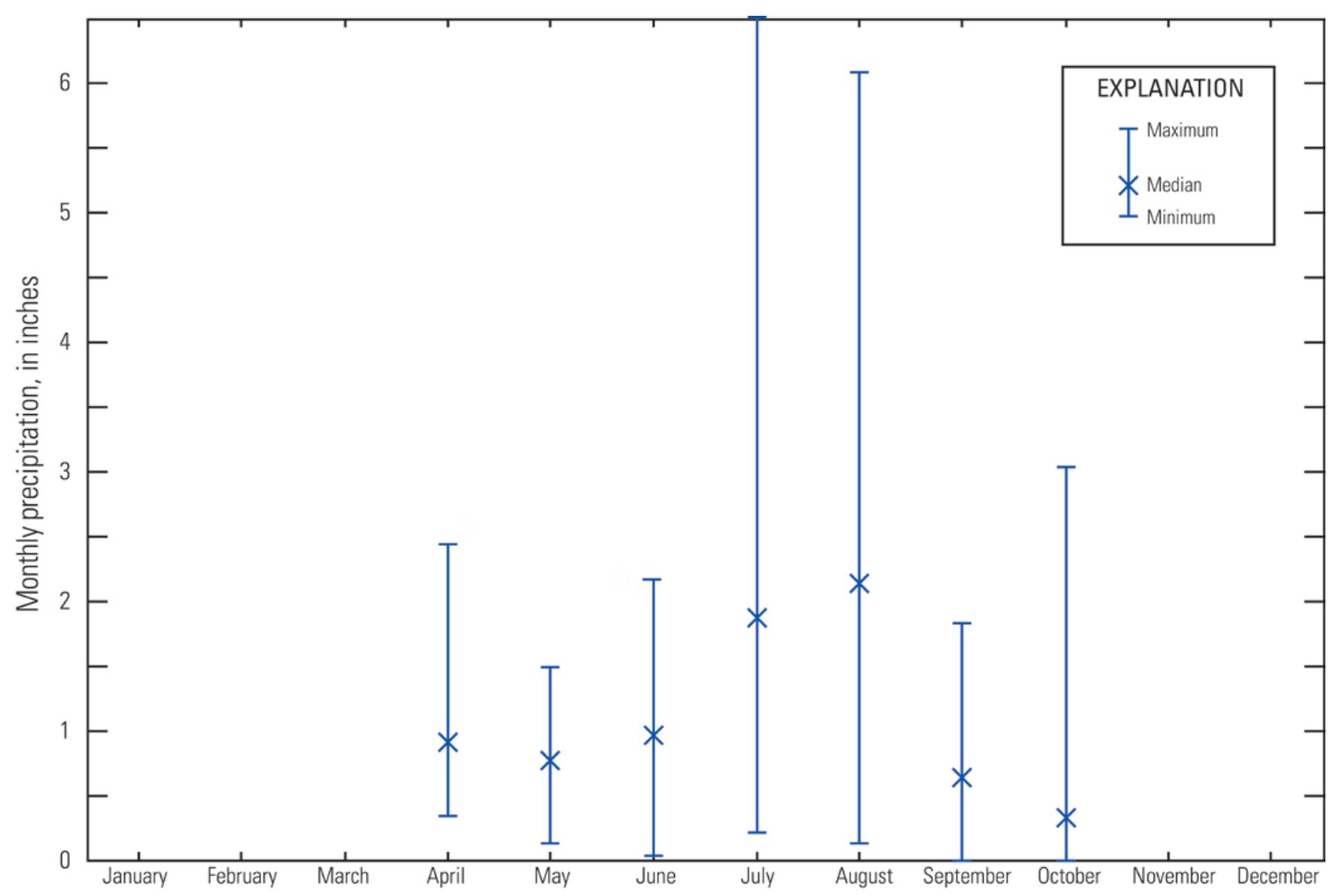

Figure 12. Maximum, minimum, and median monthly precipitation for seasonally monitored Piñon Canyon Maneuver Site precipitation stations, 2008-2012. 


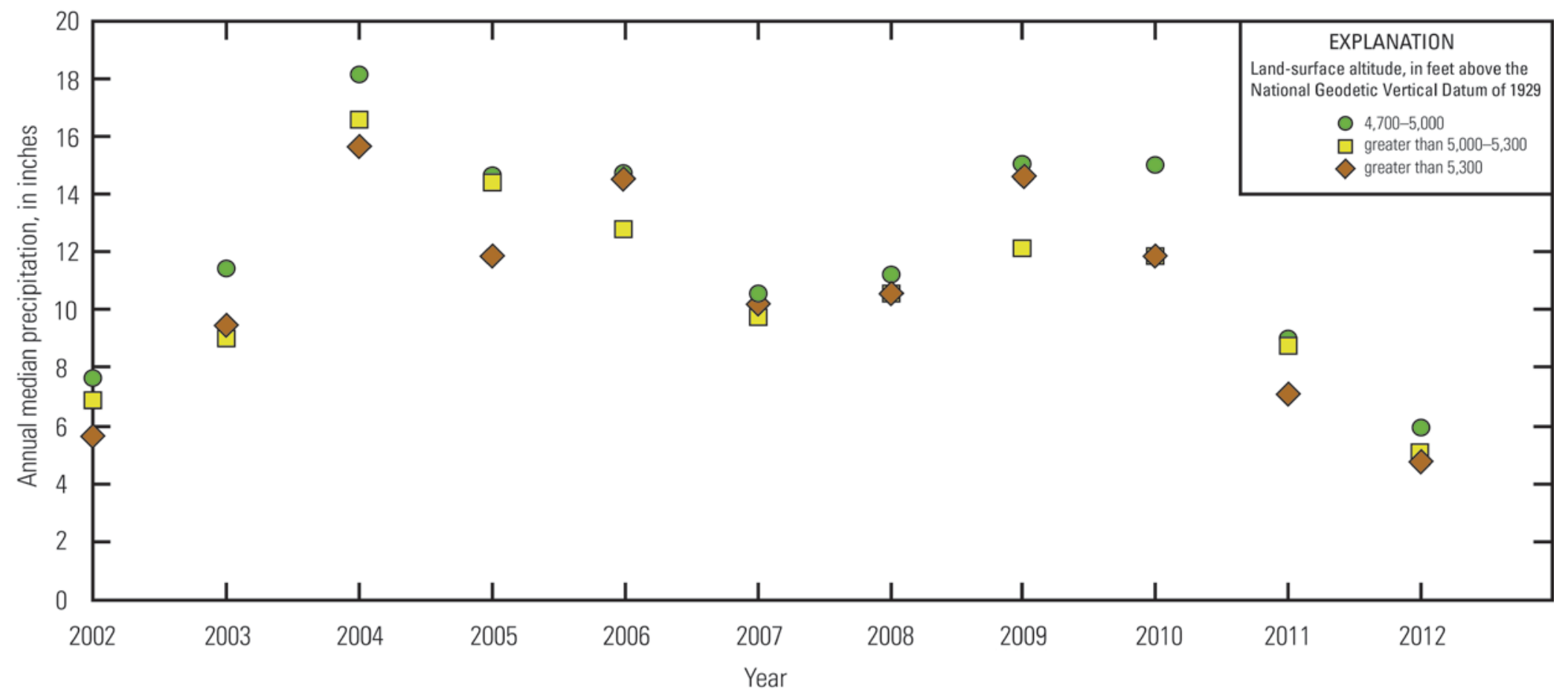

Figure 13. A. Annual median precipitation by land-surface altitude (LSA) for the Piñon Canyon Maneuver Site, $2002-2012$. 


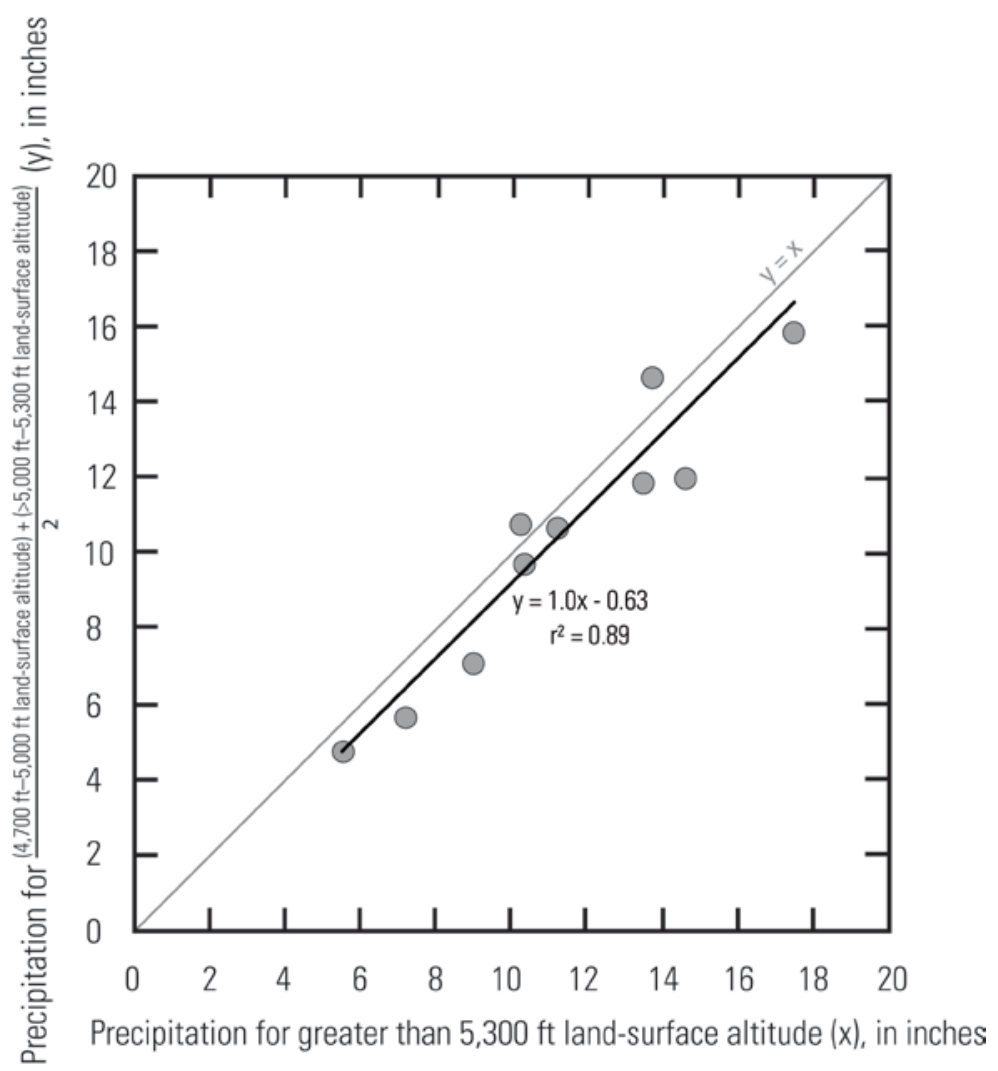

Figure 13. B. Comparison of precipitation amounts between different land-surface altitude (LSA) groups for the Piñon Canyon Maneuver Site, 2002-2012. 


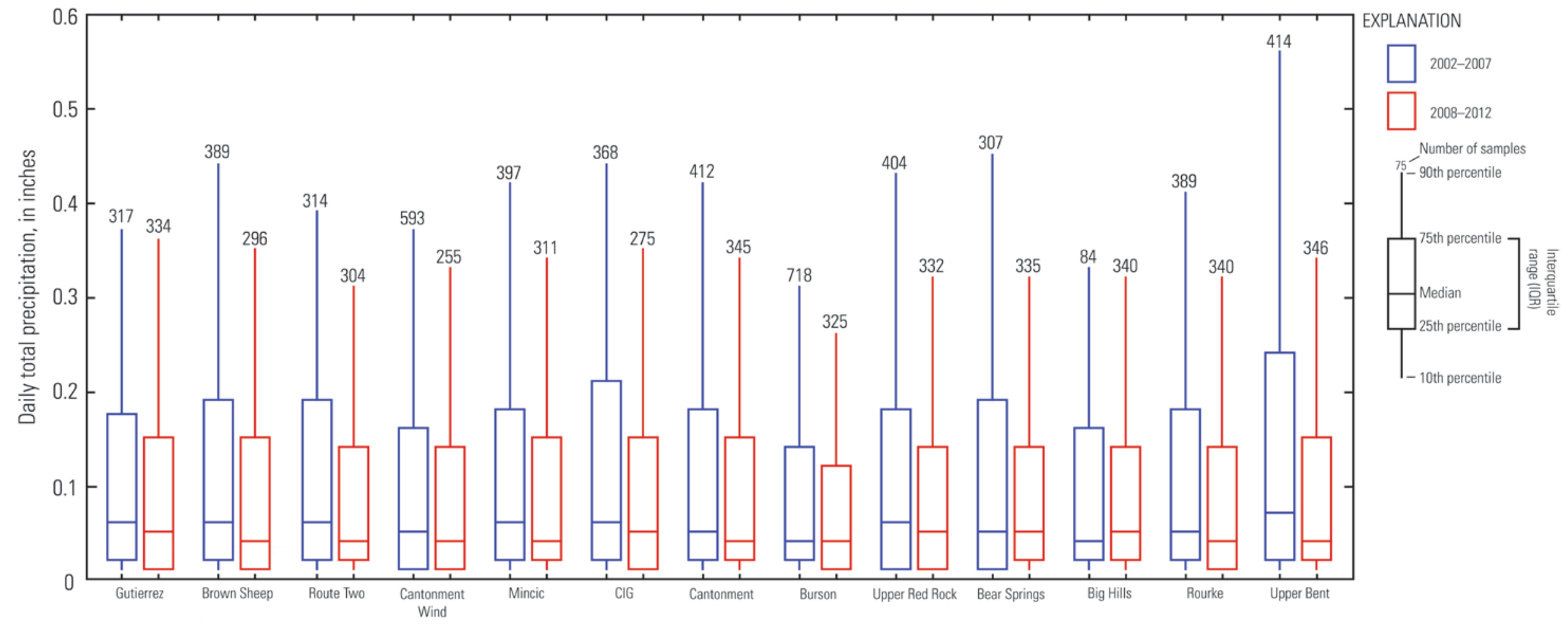

Figure 14. Censored and truncated box plots showing daily precipitation values for Piñon Canyon Maneuver Site precipitation stations. Complete station names are in table 2. 


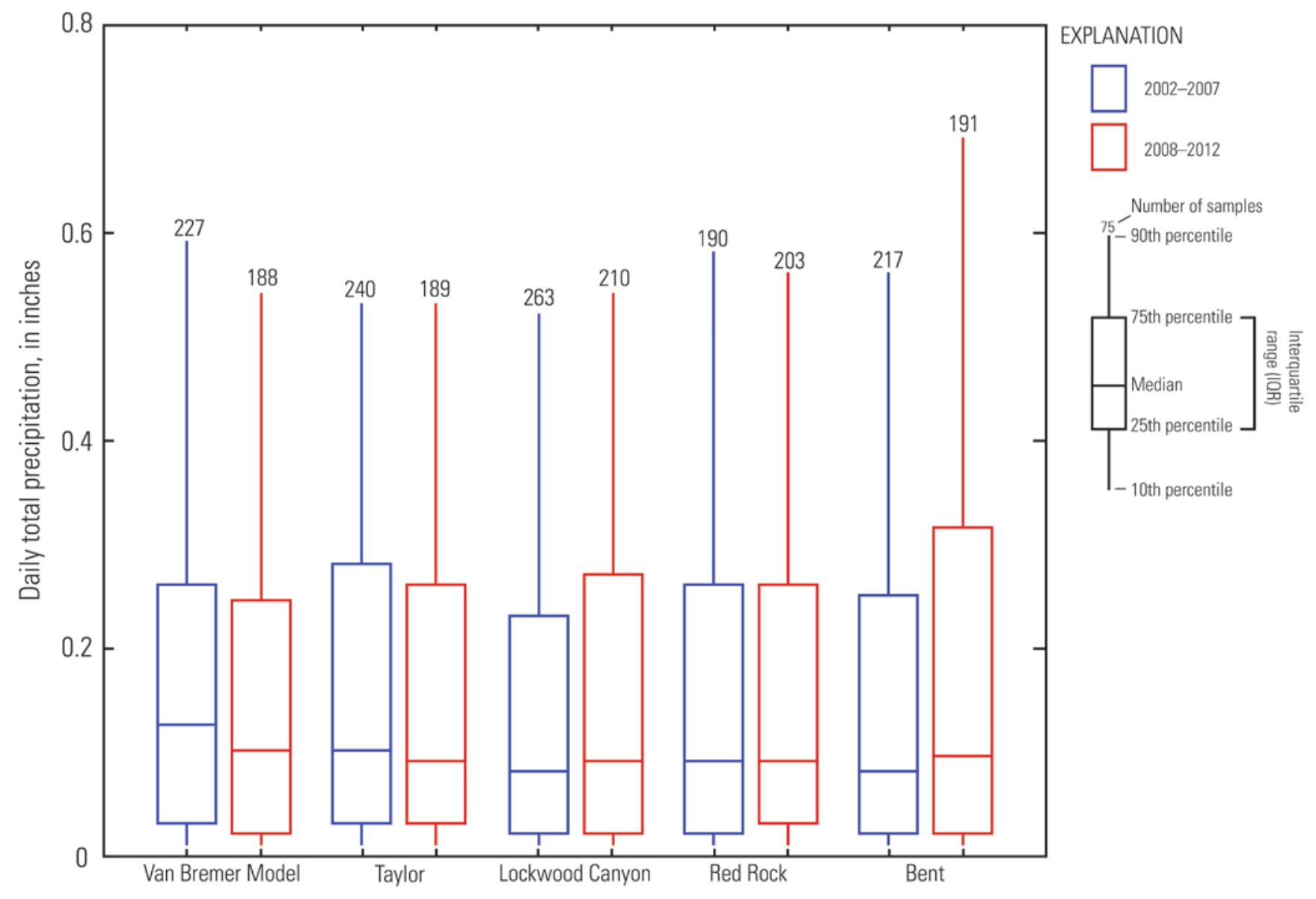

Figure 15. Censored and truncated box plots showing daily precipitation values for seasonally monitored Piñon Canyon Maneuver Site precipitation stations. Complete station names are in table 2. 


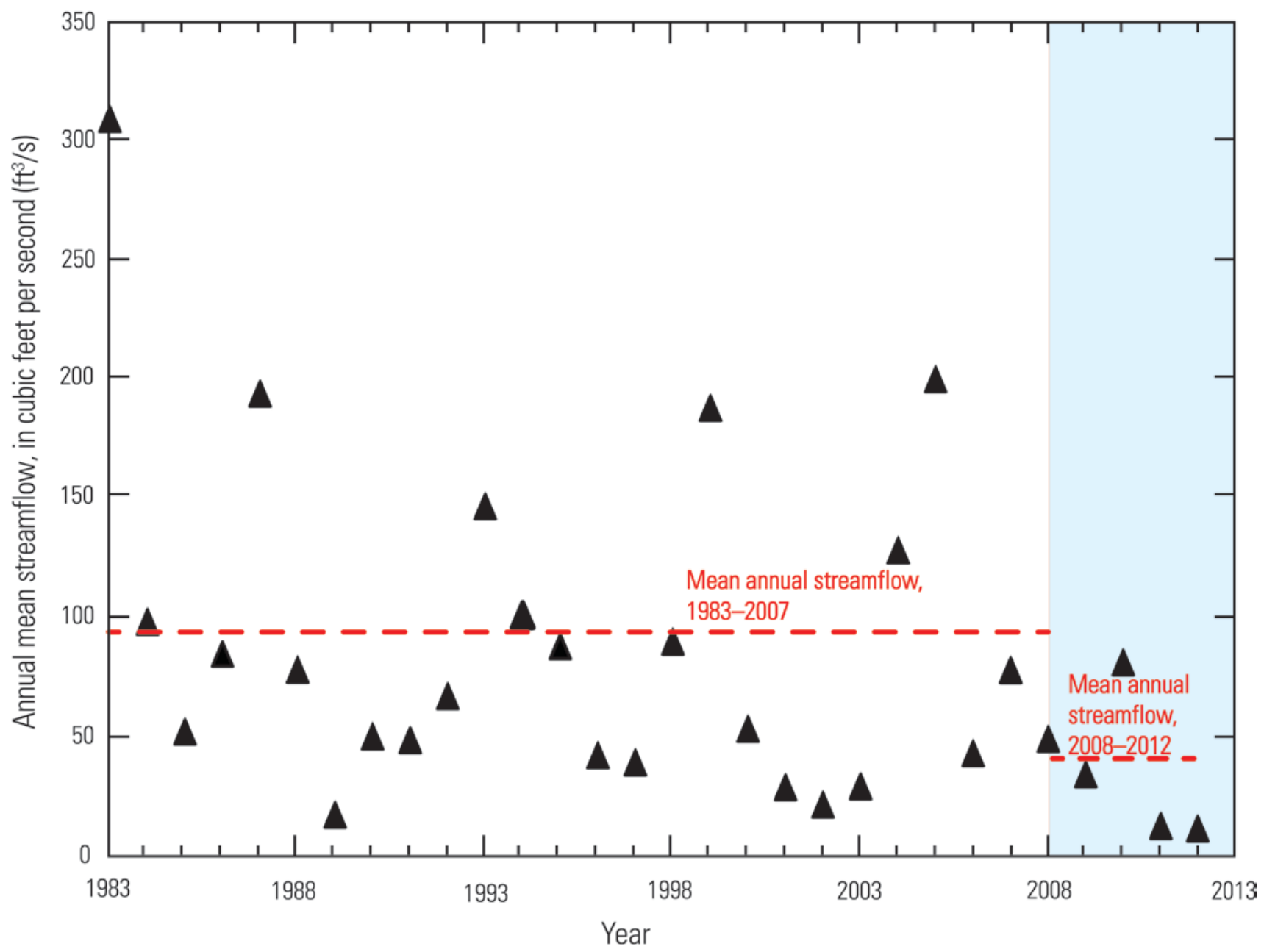

Figure 16. Annual mean streamflow for Purgatoire River near Thatcher (USGS site number 07126300, Purgatoire Thatcher). 


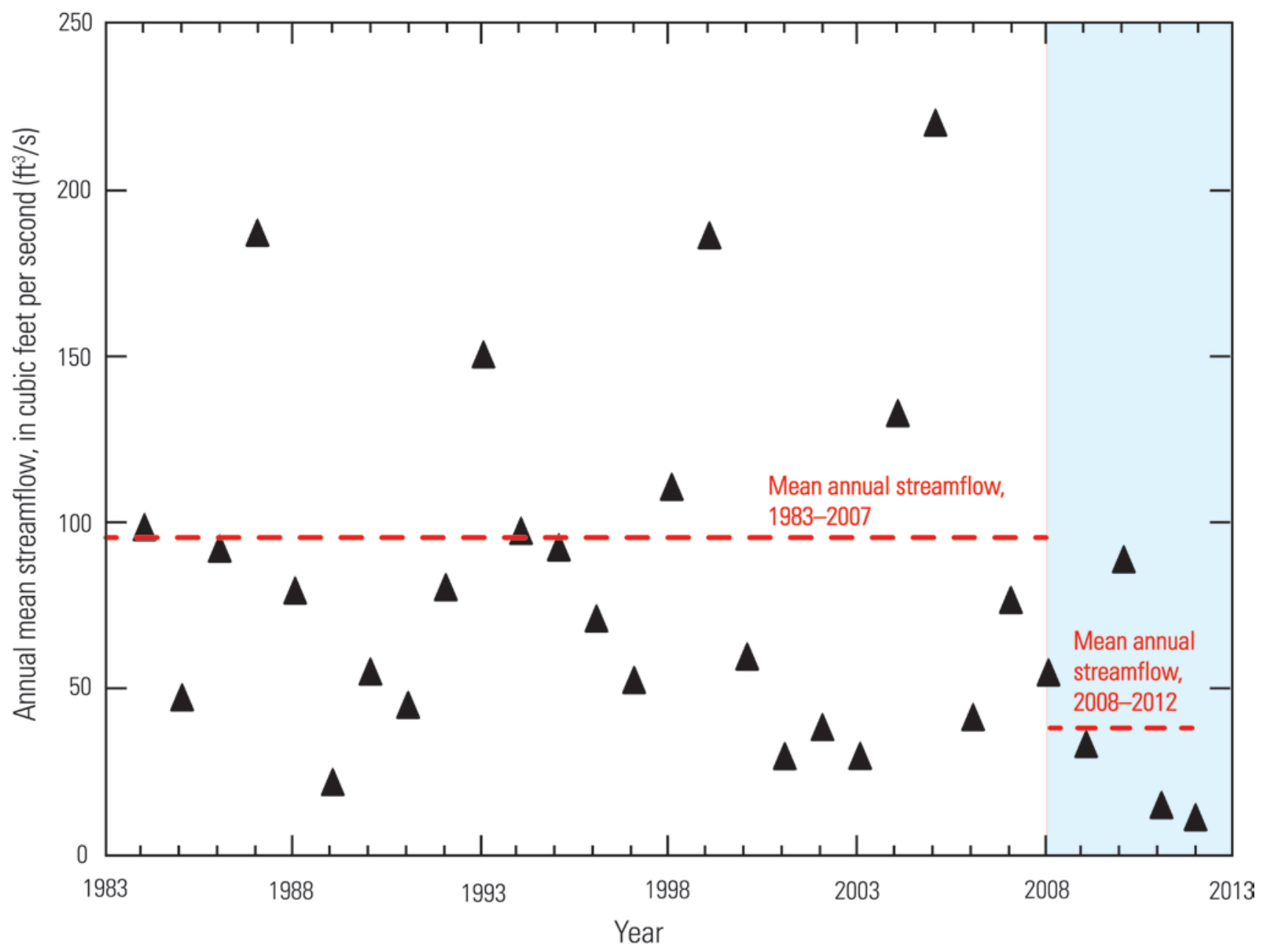

Figure 17. Annual mean streamflow for Purgatoire River at Rock Crossing (USGS site number 07126485, Purgatoire Rock Crossing). 


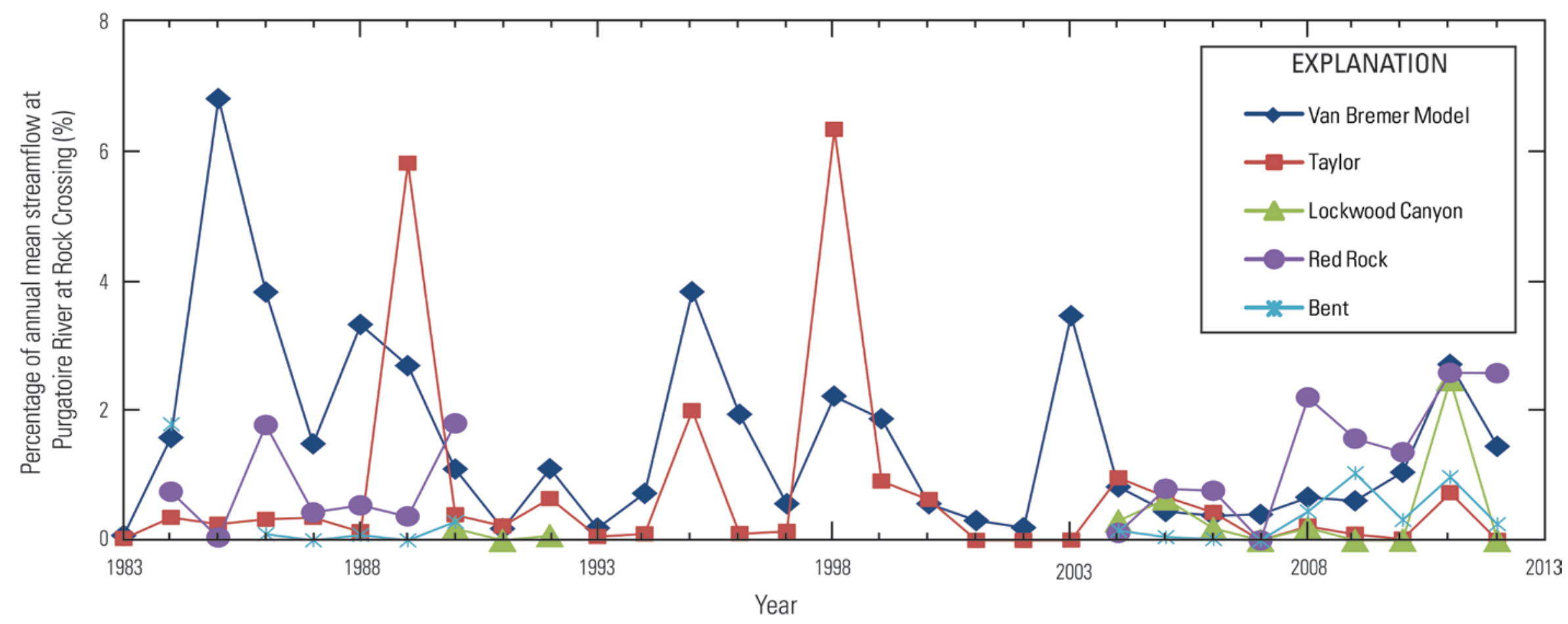

Figure 18. Percentage of annual mean streamflow at Purgatoire Rock Crossing (USGS site number 07126485) for tributary channels, Piñon Canyon Maneuver Site. 


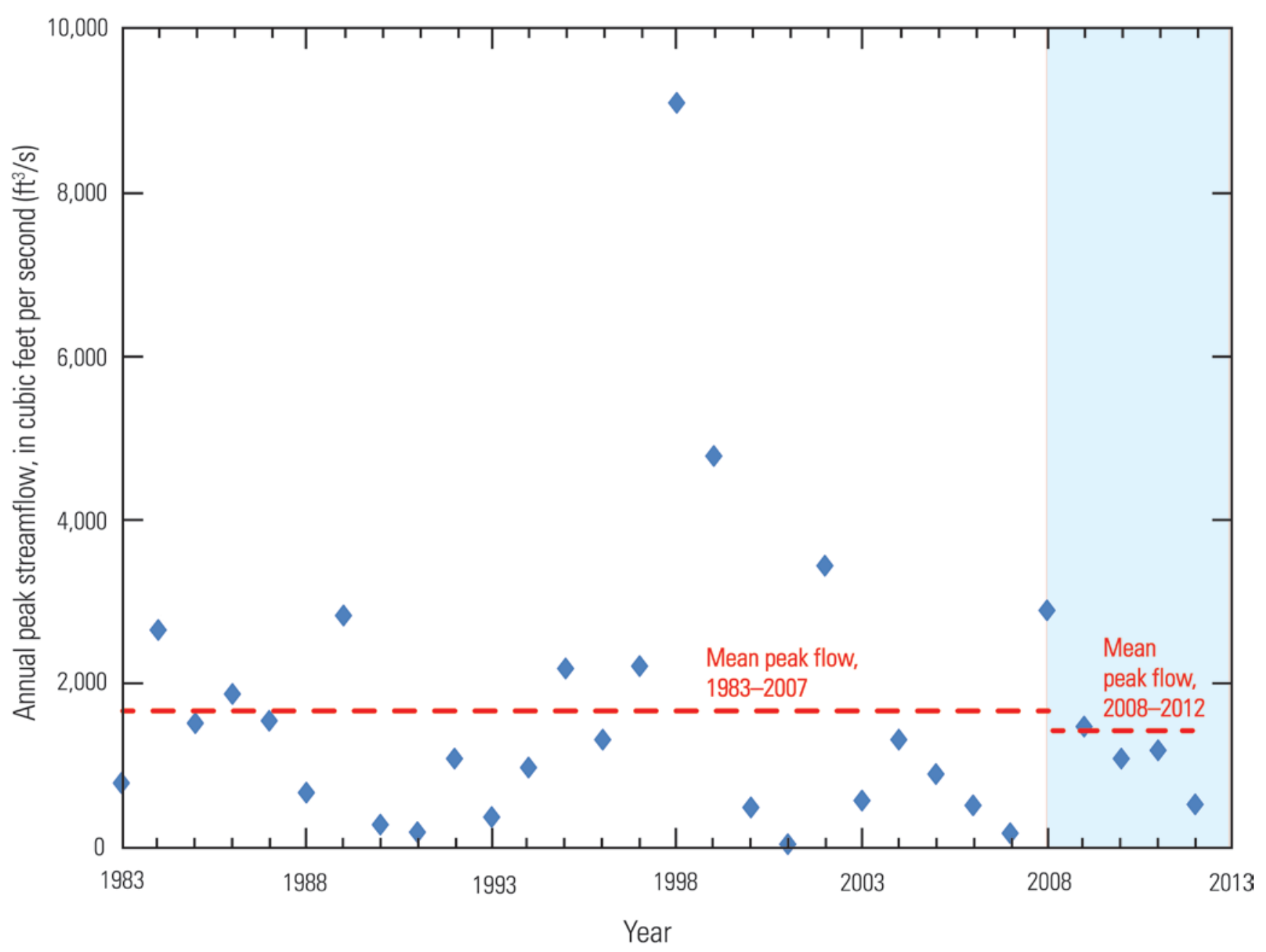

Figure 19. Annual peak flow for six tributary stream-gaging stations (Big Arroyo, Van Bremer Model, Taylor, Lockwood Canyon, Red Rock, Bent) at the Piñon Canyon Maneuver Site, 1983-2012. 


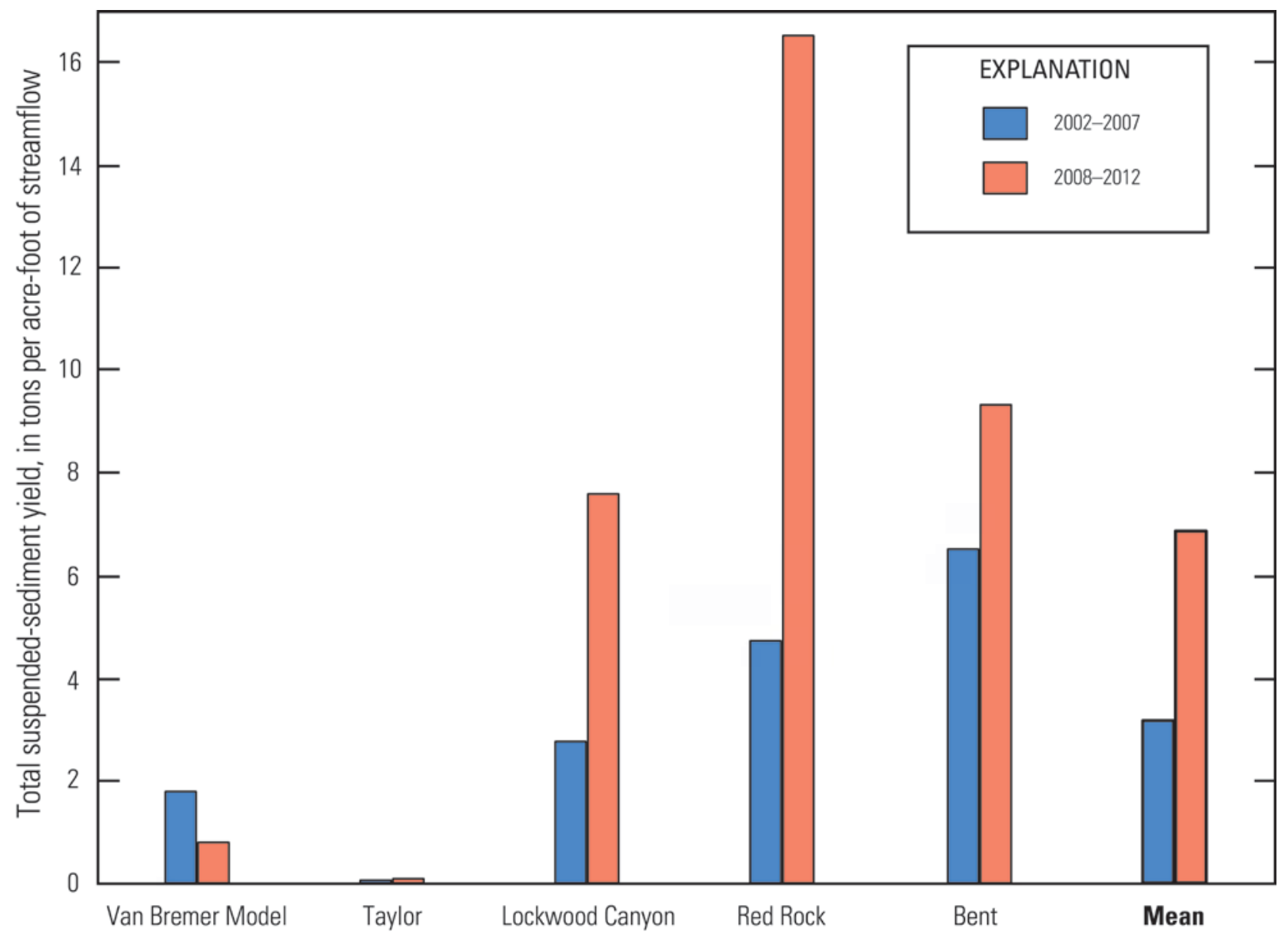

Figure 20. Total suspended-sediment yield for seasonally monitored suspended-sediment stations at the Piñon Canyon Maneuver Site: 2002-2007 and 2008-2012. 


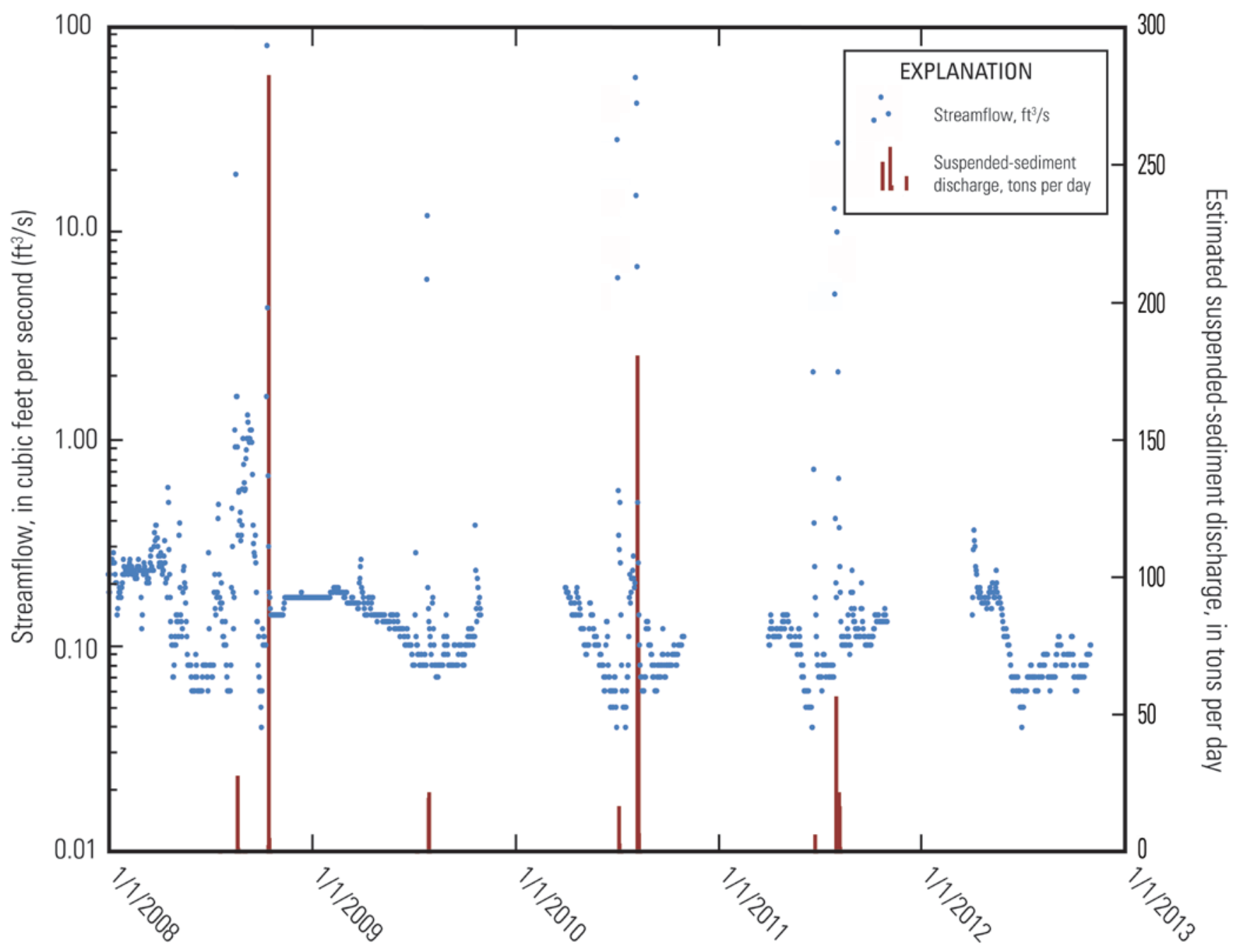

Figure 21. Daily mean streamflow and suspended-sediment discharge for Van Bremer Arroyo near Model (USGS site number 07126200, Van Bremer Model), 2008-2012. 


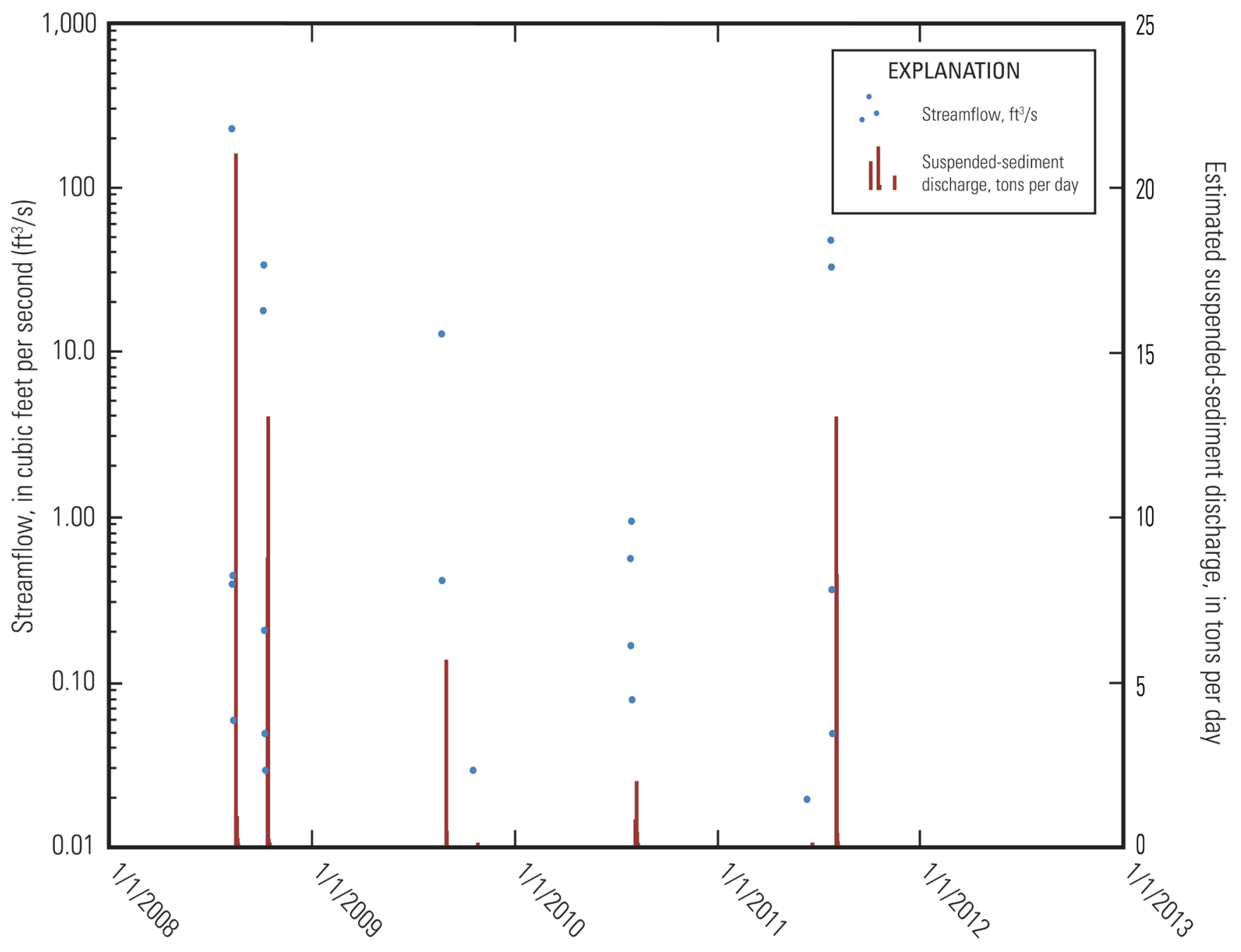

Figure 22. Daily mean streamflow and suspended-sediment discharge for Taylor Arroyo below Rock Crossing (USGS site number 07126325, Taylor), 2008-2012. 


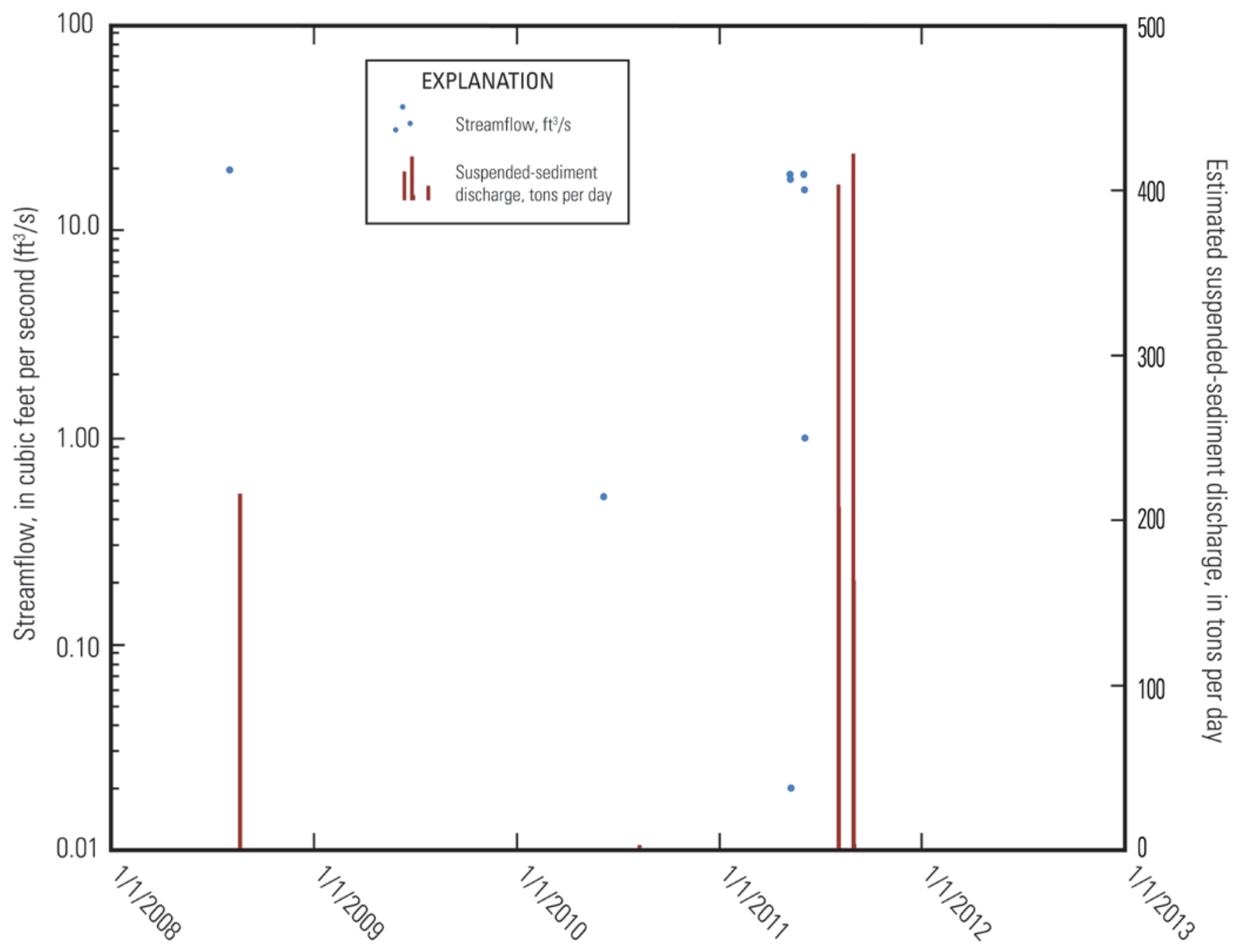

Figure 23. Daily mean streamflow and suspended-sediment discharge for Lockwood Canyon Creek near Thatcher (USGS site number 07126390, Lockwood Canyon), 2008-2012. 


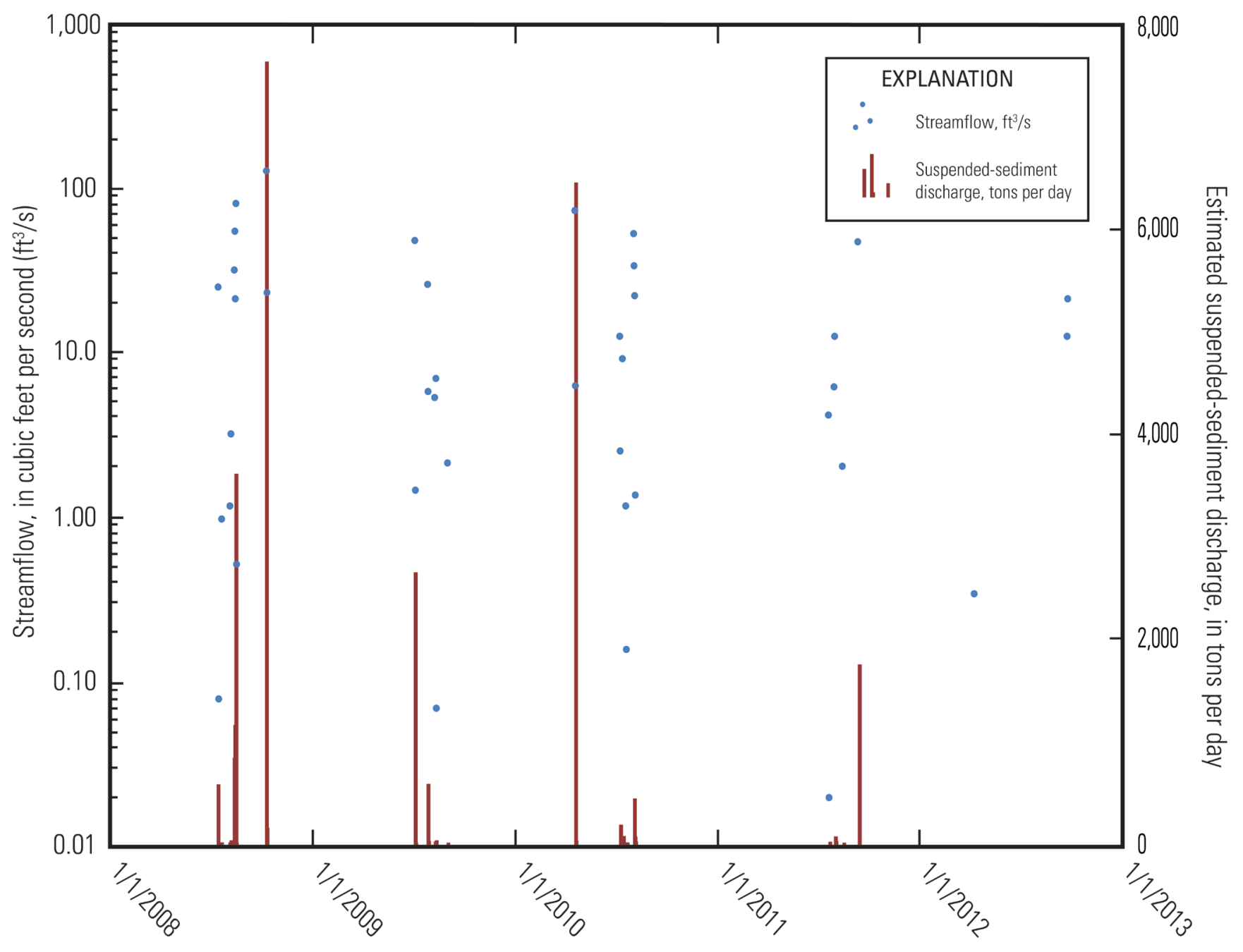

Figure 24. Daily mean streamflow and suspended-sediment discharge for Red Rock Canyon at the mouth (USGS site number 07126415, Red Rock), 2008-2012. 


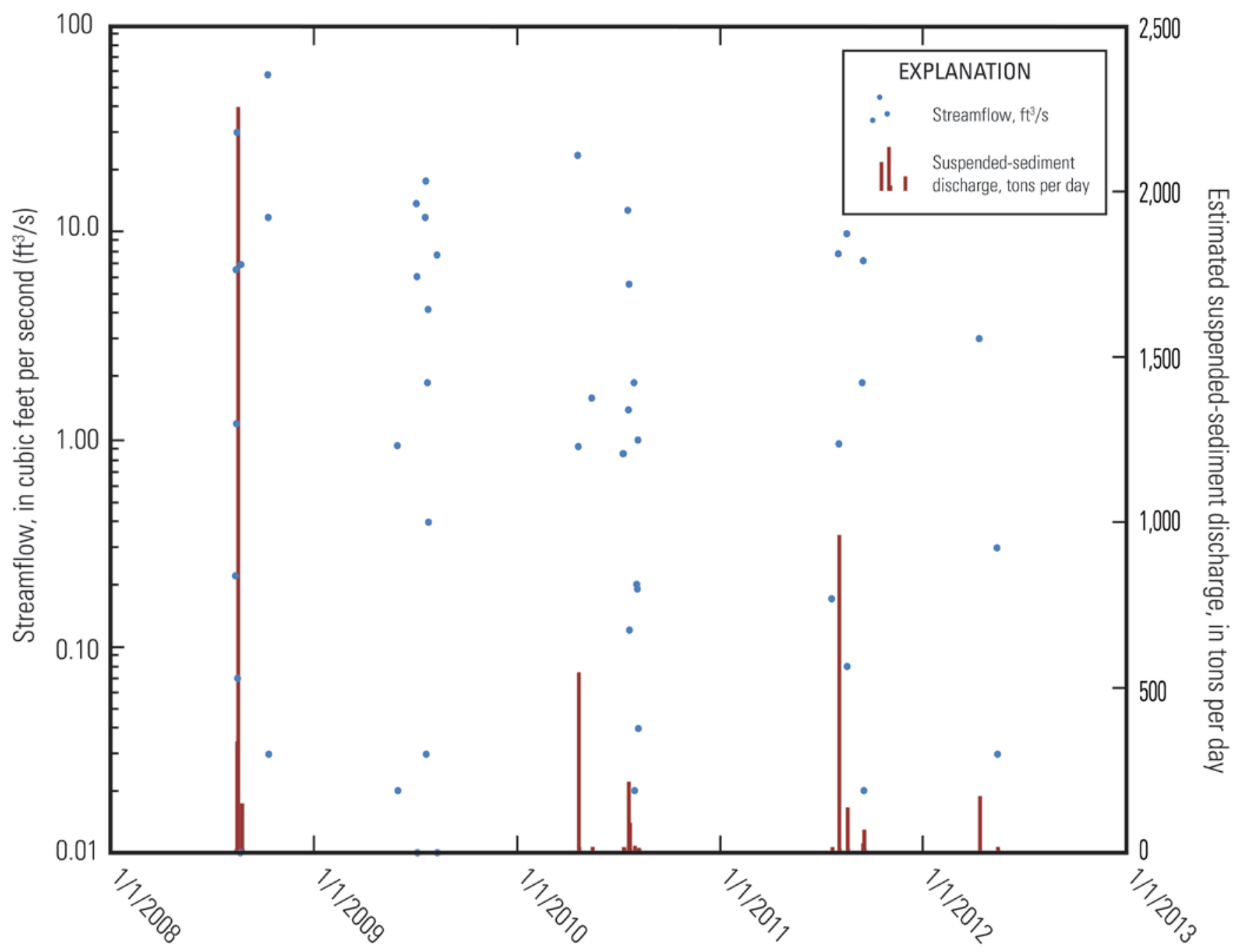

Figure 25. Daily mean streamflow and suspended-sediment discharge for Bent Canyon Creek at the mouth (USGS site number 07126480, Bent), 2008-2012. 
Table 1. Locations of the Fort Carson Military Reservation precipitation and stream-gaging stations.

\begin{tabular}{|c|c|c|c|c|c|}
\hline $\begin{array}{l}\text { U.S. Geological Survey } \\
\text { station number }\end{array}$ & Station name & Short name & Latitude & Longitude & $\begin{array}{c}\text { Land-surface } \\
\text { altitude } \\
\text { (ft above NGVD 29) }\end{array}$ \\
\hline \multicolumn{6}{|c|}{ Precipitation-monitoring stations } \\
\hline 382731104473701 & MPRC & MPRC & $38^{\circ} 27^{\prime} 31^{\prime \prime}$ & $104^{\circ} 47^{\prime} 37^{\prime \prime}$ & 5,800 \\
\hline 383109104431301 & Young Hollow & Young Hollow & $38^{\circ} 31^{\prime} 09^{\prime \prime}$ & $104^{\circ} 43^{\prime} 13^{\prime \prime}$ & 5,350 \\
\hline 383159104540701 & Sullivan Park & Sullivan Park & $38^{\circ} 31^{\prime} 59^{\prime \prime}$ & $104^{\circ} 54^{\prime} 07^{\prime \prime}$ & 6,010 \\
\hline 383713104433401 & Range 111 & Range 111 & $38^{\circ} 37^{\prime} 13^{\prime \prime}$ & $104^{\circ} 43^{\prime} 34^{\prime \prime}$ & 5,600 \\
\hline 384053104492001 & Rod and Gun & Rod and Gun & $38^{\circ} 40^{\prime} 53^{\prime \prime}$ & $104^{\circ} 49^{\prime} 20^{\prime \prime}$ & 6,120 \\
\hline \multicolumn{6}{|c|}{ Stream-gaging stations } \\
\hline 382628104493700 & Turkey Creek West Seepage below Teller Res & Turkey West & $38^{\circ} 26^{\prime} 28^{\prime \prime}$ & $104^{\circ} 49^{\prime} 37^{\prime \prime}$ & 5,420 \\
\hline 382629104493000 & Turkey Creek East Seepage below Teller Res & Turkey East & $38^{\circ} 26^{\prime} 29^{\prime \prime}$ & $104^{\circ} 49^{\prime} 33^{\prime \prime}$ & 5,420 \\
\hline 383619104520401 & Lytle Ditch & Lytle Ditch & $38^{\circ} 36^{\prime} 19^{\prime \prime}$ & $104^{\circ} 52^{\prime} 04^{\prime \prime}$ & 6,270 \\
\hline 383637104531301 & Strobel Ditch from Turkey Creek & Stroble Ditch & $38^{\circ} 36^{\prime} 37^{\prime \prime}$ & $104^{\circ} 53^{\prime} 13^{\prime \prime}$ & 6,370 \\
\hline 383944104474201 & Merriam's Little Fountain Ditch & Merriam's LF Ditch & $38^{\circ} 39^{\prime} 44^{\prime \prime}$ & $104^{\circ} 47^{\prime} 42^{\prime \prime}$ & 5,770 \\
\hline 384037104472001 & Merriam's Rock Creek Ditch & Merriam's RC Ditch & $38^{\circ} 40^{\prime} 37^{\prime \prime}$ & $104^{\circ} 47^{\prime} 20^{\prime \prime}$ & 5,830 \\
\hline 384047104510301 & Ripley Ditch from Little Fountain Creek & Ripley Ditch & $38^{\circ} 40^{\prime} 47^{\prime \prime}$ & $104^{\circ} 51^{\prime} 03^{\prime \prime}$ & 6,340 \\
\hline 384048104504901 & Womack Ditch from Little Fountain Creek & Womack Ditch & $38^{\circ} 40^{\prime} 48^{\prime \prime}$ & $104^{\circ} 50^{\prime} 49^{\prime \prime}$ & 6,370 \\
\hline 384220104503701 & Gale Ditch from Rock Creek & Gale Ditch & $38^{\circ} 42^{\prime} 20^{\prime \prime}$ & $104^{\circ} 50^{\prime} 37^{\prime \prime}$ & 6,380 \\
\hline 07099080 & Red Creek below Sullivan Park & $\operatorname{Red}^{1}$ & $38^{\circ} 29^{\prime} 59^{\prime \prime}$ & $104^{\circ} 54^{\prime} 48^{\prime \prime}$ & 5,783 \\
\hline 07099215 & Turkey Creek near Fountain & Turkey Fountain & $38^{\circ} 36^{\prime} 42^{\prime \prime}$ & $104^{\circ} 53^{\prime} 39^{\prime \prime}$ & 6,420 \\
\hline 07099230 & Turkey Creek above Teller Reservoir & Turkey Teller & $38^{\circ} 27^{\prime} 54^{\prime \prime}$ & $104^{\circ} 49^{\prime} 36^{\prime \prime}$ & 5,520 \\
\hline 07099233 & Teller Reservoir near Stone City & Teller Stone & $38^{\circ} 26^{\prime} 33^{\prime \prime}$ & $104^{\circ} 49^{\prime} 33^{\prime \prime}$ & 5,453 \\
\hline 07099235 & Turkey Creek near Stone City & Turkey Stone & $38^{\circ} 25^{\prime} 56^{\prime \prime}$ & $104^{\circ} 49^{\prime} 58^{\prime \prime}$ & 5,350 \\
\hline 07105945 & Rock Creek above Fort Carson & Rock & $38^{\circ} 42^{\prime} 27^{\prime \prime}$ & $104^{\circ} 50^{\prime} 46^{\prime \prime}$ & 6,390 \\
\hline
\end{tabular}

${ }^{1}$ Station is monitored for peak flow only. 
Table 2. Locations of the Piñon Canyon Maneuver Site precipitation, stream-gaging, and suspended-sediment stations.

\begin{tabular}{|c|c|c|c|c|c|}
\hline $\begin{array}{l}\text { U.S. Geological Survey } \\
\text { station number }\end{array}$ & Station name & Short name & Latitude & Longitude & $\begin{array}{c}\text { Land-surface } \\
\text { altitude } \\
\text { (ft above NGVD 29) }\end{array}$ \\
\hline \multicolumn{6}{|c|}{ Precipitation-monitoring stations } \\
\hline 372249103573302 & Gutierrez Windmill & Gutierrez & $37^{\circ} 22^{\prime} 49^{\prime \prime}$ & $103^{\circ} 57^{\prime} 33^{\prime \prime}$ & 5,130 \\
\hline 372319104073301 & Brown Sheep Camp & Brown Sheep & $37^{\circ} 23^{\prime} 19^{\prime \prime}$ & $104^{\circ} 07^{\prime} 33^{\prime \prime}$ & 5,390 \\
\hline 372329104020501 & Route Two Windmill & Route Two & $37^{\circ} 23^{\prime} 29^{\prime \prime}$ & $104^{\circ} 02^{\prime} 05^{\prime \prime}$ & 5,255 \\
\hline 372532104093001 & Cantonment Windmill & Cantonment Wind & $37^{\circ} 25^{\prime} 32^{\prime \prime}$ & $104^{\circ} 09^{\prime} 30^{\prime \prime}$ & 5,460 \\
\hline 372701103514501 & Mincic & Mincic & $37^{\circ} 27^{\prime} 01^{\prime \prime}$ & $103^{\circ} 51^{\prime} 45^{\prime \prime}$ & 5,078 \\
\hline 372721103595601 & CIG Pipeline South & $\mathrm{CIG}^{1}$ & $37^{\circ} 27^{\prime} 21^{\prime \prime}$ & $103^{\circ} 59^{\prime} 56^{\prime \prime}$ & 5,220 \\
\hline 372959104092201 & Cantonment & Cantonment & $37^{\circ} 29^{\prime} 59^{\prime \prime}$ & $104^{\circ} 09^{\prime} 35^{\prime \prime}$ & 5,630 \\
\hline 373004104032001 & Burson Well & Burson & $37^{\circ} 30^{\prime} 04^{\prime \prime}$ & $104^{\circ} 03^{\prime} 20^{\prime \prime}$ & 5,200 \\
\hline 373232103555201 & Bear Springs Hills & Bear Springs $^{2}$ & $37^{\circ} 32^{\prime} 32^{\prime \prime}$ & $103^{\circ} 55^{\prime} 55^{\prime \prime}$ & 5,200 \\
\hline 373315103493101 & Upper Red Rock Canyon & Upper Red Rock ${ }^{3}$ & $37^{\circ} 33^{\prime} 12^{\prime \prime}$ & $103^{\circ} 49^{\prime} 30^{\prime \prime}$ & 4,860 \\
\hline 373316103592401 & Big Arroyo Hills & Big Hills & $37^{\circ} 33^{\prime} 16^{\prime \prime}$ & $103^{\circ} 59^{\prime} 24^{\prime \prime}$ & 5,500 \\
\hline 373706103410701 & Rourke & Rourke & $37^{\circ} 37^{\prime} 06^{\prime \prime}$ & $103^{\circ} 41^{\prime} 07^{\prime \prime}$ & 4,700 \\
\hline 373823103465601 & Upper Bent Canyon & Upper Bent ${ }^{4}$ & $37^{\circ} 38^{\prime} 20^{\prime \prime}$ & $103^{\circ} 46^{\prime} 55^{\prime \prime}$ & 4,860 \\
\hline 07126200 & Van Bremer Arroyo near Model & Van Bremer Model $^{5}$ & $37^{\circ} 20^{\prime} 44^{\prime \prime}$ & $103^{\circ} 57^{\prime} 27^{\prime \prime}$ & 4,960 \\
\hline 07126325 & Taylor Arroyo below Rock Crossing & Taylor ${ }^{5}$ & $37^{\circ} 37^{\prime} 06^{\prime \prime}$ & $103^{\circ} 35^{\prime} 35^{\prime \prime}$ & 4,982 \\
\hline 07126390 & Lockwood Canyon Creek near Thatcher & Lockwood Canyon ${ }^{5}$ & $37^{\circ} 29^{\prime} 34^{\prime \prime}$ & $103^{\circ} 49^{\prime} 39^{\prime \prime}$ & 4,785 \\
\hline 07126415 & Red Rock Canyon Creek at the mouth & Red Rock ${ }^{5}$ & $37^{\circ} 30^{\prime} 55^{\prime \prime}$ & $103^{\circ} 43^{\prime} 30^{\prime \prime}$ & 4,510 \\
\hline 07126480 & Bent Canyon Creek at the mouth & Bent $^{5}$ & $37^{\circ} 35^{\prime} 21^{\prime \prime}$ & $103^{\circ} 38^{\prime} 52^{\prime \prime}$ & 4,402 \\
\hline \multicolumn{6}{|c|}{ Stream-gaging stations } \\
\hline 372308104081801 & Unnamed Tributary above Van Bremer Arroyo & Unnamed Trib $^{6}$ & $37^{\circ} 23^{\prime} 08^{\prime \prime}$ & $104^{\circ} 08^{\prime} 18^{\prime \prime}$ & 5,364 \\
\hline 373217103570701 & Lockwood Arroyo below Big Arroyo Hills & Lockwood Arroyo $^{6}$ & $37^{\circ} 32^{\prime} 17^{\prime \prime}$ & $103^{\circ} 57^{\prime} 07^{\prime \prime}$ & 5,185 \\
\hline 373235103564701 & West Fork Lockwood Arroyo below Bear Spring Hills & West Lockwood ${ }^{6}$ & $37^{\circ} 32^{\prime} 35^{\prime \prime}$ & $103^{\circ} 56^{\prime} 47^{\prime \prime}$ & 5,169 \\
\hline 373325104002701 & South Fork Big Arroyo near Houghton & South Big ${ }^{6}$ & $37^{\circ} 33^{\prime} 25^{\prime \prime}$ & $104^{\circ} 00^{\prime} 27^{\prime \prime}$ & 5,311 \\
\hline 373334103550601 & North Fork Lockwood Arroyo below Bear Spring Hills & North Lockwood ${ }^{6}$ & $37^{\circ} 33^{\prime} 34^{\prime \prime}$ & $103^{\circ} 55^{\prime} 06^{\prime \prime}$ & 5,175 \\
\hline 373556103555101 & Middle Bear Springs Arroyo at Boundary & Middle Bear ${ }^{6}$ & $37^{\circ} 35^{\prime} 56^{\prime \prime}$ & $103^{\circ} 55^{\prime} 51^{\prime \prime}$ & 5,177 \\
\hline 373556103575201 & West Bear Springs Arroyo at Boundary & West Bear ${ }^{6}$ & $37^{\circ} 35^{\prime} 56^{\prime \prime}$ & $103^{\circ} 57^{\prime} 52^{\prime \prime}$ & 5,108 \\
\hline 373635103542901 & East Bear Springs Arroyo at Boundary & East Bear ${ }^{6}$ & $37^{\circ} 36^{\prime} 35^{\prime \prime}$ & $103^{\circ} 54^{\prime} 29^{\prime \prime}$ & 5,220 \\
\hline 07120620 & Big Arroyo near Thatcher & Big Arroyo ${ }^{6}$ & $37^{\circ} 33^{\prime} 17^{\prime \prime}$ & $104^{\circ} 01^{\prime} 16^{\prime \prime}$ & 5,288 \\
\hline
\end{tabular}


Table 2. Locations of the Piñon Canyon Maneuver Site precipitation, stream-gaging, and suspended-sediment stations.-Continued

\begin{tabular}{|c|c|c|c|c|c|}
\hline $\begin{array}{l}\text { U.S. Geological Survey } \\
\text { station number }\end{array}$ & Station name & Short name & Latitude & Longitude & $\begin{array}{c}\text { Land-surface } \\
\text { altitude } \\
\text { (ft above NGVD 29) }\end{array}$ \\
\hline 07126130 & Van Bremer Arroyo near Thatcher & Van Bremer Thatcher ${ }^{6}$ & $37^{\circ} 24^{\prime} 36^{\prime \prime}$ & $104^{\circ} 10^{\prime} 06^{\prime \prime}$ & 5,400 \\
\hline 07126140 & Van Bremer Arroyo near Tyrone & Van Bremer Tyrone ${ }^{6}$ & $37^{\circ} 23^{\prime} 58^{\prime \prime}$ & $104^{\circ} 06^{\prime} 55^{\prime \prime}$ & 5,310 \\
\hline 07126200 & Van Bremer Arroyo near Model & Van Bremer Model & $37^{\circ} 20^{\prime} 44^{\prime \prime}$ & $103^{\circ} 57^{\prime} 27^{\prime \prime}$ & 4,960 \\
\hline 07126300 & Purgatoire River near Thatcher & Purgatoire Thatcher & $37^{\circ} 21^{\prime} 23^{\prime \prime}$ & $103^{\circ} 53^{\prime} 59^{\prime \prime}$ & 4,790 \\
\hline 07126325 & Taylor Arroyo below Rock Crossing & Taylor & $37^{\circ} 25^{\prime} 27^{\prime \prime}$ & $103^{\circ} 55^{\prime} 11^{\prime \prime}$ & 4,982 \\
\hline 07126390 & Lockwood Canyon Creek near Thatcher & Lockwood Canyon & $37^{\circ} 29^{\prime} 34^{\prime \prime}$ & $103^{\circ} 49^{\prime} 39^{\prime \prime}$ & 4,785 \\
\hline 07126415 & Red Rock Canyon Creek at the mouth & Red Rock & $37^{\circ} 30^{\prime} 55^{\prime \prime}$ & $103^{\circ} 43^{\prime} 30^{\prime \prime}$ & 4,510 \\
\hline 07126480 & Bent Canyon Creek at the mouth & Bent & $37^{\circ} 35^{\prime} 21^{\prime \prime}$ & $103^{\circ} 38^{\prime} 52^{\prime \prime}$ & 4,402 \\
\hline 07126485 & Purgatoire River at Rock Crossing & Purgatoire Rock Crossing & $37^{\circ} 37^{\prime} 06^{\prime \prime}$ & $103^{\circ} 35^{\prime} 35^{\prime \prime}$ & 4,350 \\
\hline \multicolumn{6}{|c|}{ Suspended-sediment monitoring stations } \\
\hline 07126200 & Van Bremer Arroyo near Model & Van Bremer Model & $37^{\circ} 20^{\prime} 44^{\prime \prime}$ & $103^{\circ} 57^{\prime} 27^{\prime \prime}$ & 4,960 \\
\hline 07126325 & Taylor Arroyo below Rock Crossing & Taylor & $37^{\circ} 25^{\prime} 27^{\prime \prime}$ & $103^{\circ} 55^{\prime} 11^{\prime \prime}$ & 4,982 \\
\hline 07126390 & Lockwood Canyon Creek near Thatcher & Lockwood Canyon & $37^{\circ} 29^{\prime} 34^{\prime \prime}$ & $103^{\circ} 49^{\prime} 39^{\prime \prime}$ & 4,785 \\
\hline 07126415 & Red Rock Canyon Creek at the mouth & Red Rock & $37^{\circ} 30^{\prime} 55^{\prime \prime}$ & $103^{\circ} 43^{\prime} 30^{\prime \prime}$ & 4,510 \\
\hline 07126480 & Bent Canyon Creek at the mouth & Bent & $37^{\circ} 35^{\prime} 21^{\prime \prime}$ & $103^{\circ} 38^{\prime} 52^{\prime \prime}$ & 4,402 \\
\hline
\end{tabular}

${ }^{1}$ Station known as "Taylor precipitation gage" in von Guerard and others (1993).

${ }^{2}$ Station known as "Lockwood precipitation gage" in von Guerard and others (1993).

${ }^{3}$ Station known as "Red Rock precipitation gage" in von Guerard and others (1993).

${ }^{4}$ Station known as "Bent Canyon precipitation gage" in von Guerard and others (1993).

${ }^{5}$ Stations are monitored seasonally (April-October).

${ }^{6}$ Stations are monitored for peak flow only. 


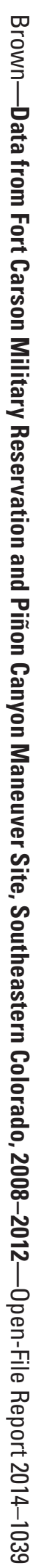

